\title{
Influential Storytelling at its Finest: Why the Postwar West Took Notice of Yasujirō Ozu's Tokyo Story
}

Abigail Deveney

Follow this and additional works at: https://gensoken.toyo.ac.jp/japanese-society-and-culture

Part of the Cultural History Commons, Film Production Commons, Language Interpretation and Translation Commons, Other Film and Media Studies Commons, Political History Commons, and the Visual Studies Commons

\section{Recommended Citation}

Deveney, Abigail (2021) "Influential Storytelling at its Finest: Why the Postwar West Took Notice of Yasujirō Ozu's Tokyo Story," Japanese Society and Culture: Vol. 3 , Article 2.

DOI: 10.52882/2434-1738-0302

Available at: https://gensoken.toyo.ac.jp/japanese-society-and-culture/vol3/iss1/2

This Article is brought to you for free and open access by Institute of Social Sciences. It has been accepted for inclusion in Japanese Society and Culture by an authorized editor of Institute of Social Sciences. 


\title{
Influential Storytelling at its Finest: Why the Postwar West Took Notice of Yasujirō Ozu's Tokyo Story
}

\author{
Abigail Deveney*
}

Abstract

Tokyo Story (1953) came to fame in 1958, when Yasujirō Ozu's postwar film about a fragmenting family won the Sutherland prize at the London Film Festival - or so cinematic scholarship suggests. There is, however, a much more complex tale to be told. In fact, director Ozu's shomingeki-genre film was being discussed and promoted internationally long before what is considered that watershed moment.

This dissertation explores why the western world took note. It argues that Tokyo Story's nuanced and humanist narrative was a unique form of soft power, attracting and persuading decades before that concept was formally articulated. Tokyo Story's uptake reflected the power of a film, initially defined within national parameters, then redeployed transnationally, to modify impressions of Japan after the second world war.

Drawing on archives, interviews, and scholarly writings, the author maps out original theories about why Tokyo Story won the Sutherland prize. Creating a space in which Ozu's mastery intersects with the priorities of government, industry and individuals, the author investigates the policies, plans and people behind the film's success. Tokyo Story's enduring narrative proved better than any emissary or delegation in evolving views of a once-warring nation. It remains cinematic artistry at its influential finest.

Keywords: Yasujirō Ozu, Film, Cinema, Japan, Japanese, Tokyo Monogatari, TokyoStory, Their First Trip to Tokyo, Shomingeki Genre, Postwar, London Film Festival, BFI, Sutherland Prize, Shochiku, Shiro Kido, Kashiko Kawakita, Nagamasa Kawakita, Donald Richie, Tadao Sato, Dilys Powell, Leslie Hardcastle, Earl Miner, John Gillett, Derek Prouse, Soft Power

Introduction: Soft power success

The year 1957 finds the vista of Japan's postwar diplomatic front opening wide in all directions Nobusuke Kishi, Japanese prime minister. (Kishi 1957:553)

... the more that we can bring our two cultures together ... the closer we will come to understanding each other ... - Richard Nixon, American vice president. (Nixon 1953:363-64)

$\ldots$ in the end, stories are about one person saying to another: This is the way it feels to me. Can you

\footnotetext{
※ffiliation:

Graduate, University of London, School of Oriental and African Studies (SOAS) MA Japanese Studies (2018).

Currently conducting independent research.
} 
understand what I'm saying? Does it also feel this way to you? - Kazuo Ishiguro, author. (Ishiguro 2017)

Yasujirō Ozu's 1953 film Tokyo Story was a unique form of soft power, its nuanced and humanist narrative embraced in the postwar period to attract and persuade. Capturing a universally accessible tale of evolving and dissolving family structures and generational fissure, the film's success after initial screenings in the mid-1950s in North America and Europe was in part the result of masterful storytelling by cinema's elder statesman. This success, however, reflected more. It showed cinema as a powerful medium, initially defined within national parameters, then redeployed transnationally to gradually shape opinions, reconstitute attitudes and create a softer image of Japan after the second world war.

Ozu the universalist probably did not direct Tokyo Story, or Tokyo Monogatari, with this outcome in mind. He was considered to have been the most Japanese of all directors, one whose contemplative pacing and low-key mise-en-scène embraced the everyday. Depicting wistful elders, shifting family mores, and juxtaposing traditional Japan with its tea cups and tatami mats against Tokyo's gritty postwar urban landscape, some film industry experts maintained Ozu would confuse a global audience. But it was the essence of this Japaneseness that earned Ozu international acclaim. With decades as a domestic cinema stalwart and fluency in transnational modes of narration, Ozu understood the power of film to influence and inform, excite and impel, through simple, elegant, and universally accessible storytelling.

But how did the most Japanese of directors emerge from national cinema to achieve transnational acclaim? In an era of great directorship, why did the west take note of Ozu and his slow-moving Tokyo Story? What fuelled the success of this shomingeki-genre film about the Everyman? Interrogating theories around national and transnational cinema, understanding Ozu's globally networked patrons, and considering political priorities of the era, this dissertation adopts an historiographical and chronological approach in reply. It draws on archival research in London, Los Angeles, and Tokyo, scholarly writings, and interviews conducted by the author with lions of this golden age. This dissertation contends that government outreach in the 1950s, as evidenced by the prime ministerial quote at the outset, assisted with Tokyo Story's transnational success as politicians grasped the power of cultural exports, something equally observed by Richard Nixon in the second quotation. It argues that the state was supported by a handful of globally networked individuals, staunch Ozu supporters who were cognisant of western production techniques, identified transnational opportunities via distribution, exhibition and film criticism, and who understood the nature of audience and reception.

Furthermore, this dissertation maps out original theories about the nature of Tokyo Story's acclaim in London in 1958, when it won the Sutherland prize at the London Film Festival, heralding what is widely considered to be Ozu's watershed moment in the west.

Creating a space in which Ozu's mastery intersects with the priorities of government, industry, and individuals, this dissertation considers the genius of Tokyo Story in a new light. And it reflects on the power of storytelling to connect, so eloquently articulated by author Kazuo Ishiguro in the third opening quotation. Attracting and influencing long before the soft power of cultural exports was formally defined by political scientist Joseph Nye in 1990 (Nye 1990), Tokyo Story is now ranked among the greatest films ever. Ozu portrayed himself as a mere maker of the everyday dish of tofu. Yet it was this simplicity that made him Japan's most compelling national and transnational storyteller, with Tokyo Story his exemplar. 
The everyday, made exceptional

Quiet is the word that springs to mind when considering Tokyo Story. The storyline is simple: aging parents venture from southwest Japan to the capital to visit their adult children (Tokyo Story 1953). That elderly parents must undertake arduous travel at all signals the staggering postwar shift underway in family dynamics (Ochiai 2000:107; Noletti 1997:30-31). The trip goes badly as preoccupied children are too busy to reconnect. The mother becomes fatigued and ill and, soon after returning home, dies. Even her passing seems an annoyance: condolences are largely perfunctory; everyday life promptly reasserts itself; and a bereaved husband is left to ponder the present, the future, and the past. It is a story of "one family, whose members are neither noble nor base but are truly ordinary in character and behaviour", yet the viewer is "profoundly moved" by the "eternal problem" of severance of parent and child (Sato 1982:193).

Depicting the packing of a lunch box for travels, discussion of train times, the sharing of rice crackers with family or the drinking of sake with friends, such was the way of shomingeki, a genre that peers into the lives of common folk, depicting difficulties using warmth, humour, sympathy, and compassion (Noletti 1997:34). It is a style "many Japanese think of as being about 'you and me" (Anderson and Richie 1982[1959]:51). And it is a style Ozu dominated in a career that began as an assistant cameraman in 1923 at Shochiku studios (Richie 1974:198). By 1926, Ozu was an assistant director; he became a full director a year later. By the 1930s, he was established as a leading director (Desser 1997:2), making dozens of films in a career that lasted until 1962. He died of cancer in 1963, at the age of 60. Ozu's talents were recognised with numerous accolades, including from influential magazine Kinema Junpo. ${ }^{1}$ Shochiku specialised in shomingeki, also known as "home drama" (Sato 1982:139). Shochiku executive Shiro Kido, who would dominate the industry for decades, articulated the need for national cinema to embrace western modernity and to depict the realities of everyday Japanese life (Joo 2017:26). An elite university graduate with a command of English, Kido was keen to adopt western filmmaking practices, emphasising the director system and scriptwriting (Joo 2017:27). Indeed, Universal City in Hollywood was the model for Shochiku's Kamata studios (Joo 2017:24). American expertise was sought in achieving Kido's corporate aims, including from Japanese-born Hollywood actor and cinematographer Henry Kotani, who brought elements of the director system from the US and contributed technical knowledge (Joo 2017:2425). Some scholars argue that this postwar studio system was pivotal in bringing Japanese cinema into line with the international mode of representation, or mainstream Hollywood style (Burch 1979; cited in Standish 2005:17).

However, Shochiku's mission extended beyond informing a genre. The drive to make western-style films was the origin of Shochiku as a film trust (Burch 1979:274). Setting out its stall in an advertisement in 1920 in Tokyo's Nichi Nichi Shimbun newspaper, Shochiku proclaimed its intent to "improve the quality of Japan's motion pictures by producing artistic films that are currently actively advocated in the West and releasing them at home and abroad" (Joo 2017:23). More important for this dissertation, however, was Shochiku's desire to "contribute to harmonious international relations among Japan and other countries by introducing the true state of people's lives ..." (Joo 2017:23), just the state Ozu depicted. As early as 1920 , then, Shochiku's leadership understood the power of cinematic narratives to influence.

1 https://www.imdb.com/name/nm0654868/awards. Accessed August 28, 2018. 
Ozu, meanwhile, went one step better with mastery of the home drama style. "Quite simply one of cinema's greatest directors, Ozu is revered for his minimalist and restrained style”, defined by a stationary camera, meditative tempo, low camera position, speakers shot full frontal, seemingly unrelated transitional shots, and narrative symmetries and ellipses (Noletti 1997:41). Ozu evolved the genre into his own; Tokyo Story stands at the apex. It can be appreciated for its universal appeal, as a story of aging parents and their disappointments, or "as a paradigm of the unique cinema of Ozu" (Desser 1997:5). Calling Tokyo Story his "most melodramatic" film (Rayns date unknown:164), Ozu drew on the 1937 Leo McCarey film Make Way for Tomorrow. Although Ozu had not seen that film, friend and writing partner Kōgo Noda had (Bordwell 1988:328). Cinema scholar Tadao Sato, who lived and worked through Ozu's times, noted the Hollywood production's influence in an interview with this author in June 2018 in Kawasaki2: "Tokyo Monogatari got the idea, the initial idea" from Make Way for Tomorrow, where David Bordwell finds similarities in theme, tone and dramatic situation (Bordwell 1988:328-29). As with Tokyo Story, McCarey's film depicts fraught socio-economic times, the difficulties of aging, and the fracturing nature of family. Bordwell suggests that Ozu, in recasting McCarey, was simply continuing a habit formed in the 1930s of borrowing from American cinema (Bordwell 1988:328). There is no doubt that Ozu understood western narrative. His Sword of Penitence (1927) was based on an American silent film from 1922 called Kick-In (Richie 1974:203), while The Dreams of Youth (1928) reflected several American pictures (Richie 1974:203). Ozu's 1929 film Fighting Friends - Japanese Style was modelled on an American series of comedies (Richie 1974:205-206). Ozu would have been exposed to Hollywood films in the late 1930s and early 1940s during military service in Singapore, "the impression of which he often mentioned with admiration after the war" (Joo 2017:148). Contemplating the notion of Japanese cinema amid increasing American cultural domination, Ozu, in postwar writings, contended that directors must exploit a unique identity, drawing on Japanese customs, traditions and background (Joo 2017:148-49).

It is evident, then, that the studio that nurtured and exploited Ozu's talents was cognisant of cinema's impact at home and abroad, and of its ability to attract and influence. It is also clear that both Ozu and Shochiku were informed of and by western cinema's production methods and narrative paths. A world promotional junket in 1955 by executive Kido and corporate outreach by Shochiku itself in Los Angeles early on in that decade would ensure the studio developed an understanding of transnational distribution methods, award and screening opportunities, and the nuances of film criticism (Davis 1996:34; Loewenthal 1955a:1). So, too, emerged an understanding of audience.

Bridging the cinema-theory space

It is appropriate, before further pondering the policies, plans and people behind Tokyo Story's advancement, to consider the theoretical discourse on cinematic nationalism and transnationalism. Scholars who interrogate these aspects of film studies struggle to agree actual definitions. Consequently, these catch-all phrases have varied meanings. Isolde Standish considers cinema as social practice in which varying and sometimes competing forces from traditional arts, sociopolitical trends and western technology were "adopted, adapted and altered to produce a cinematic tradition" (Standish 2005:14). "Images and cinema should be understood as part of the social process of the creation of meaning," Standish writes, in seeking to affirm the link between a film, its contents, production, reception and the

2 Personal communication. Tadao Sato consented to be interviewed and quoted. See Appendix A. 
realities of life, politics, societies and events (Standish 2005:25). This dissertation concurs.

Academic Andrew Higson is among the commentators on national cinema. His 1989 writing on the subject is seminal, although he has revisited those views (Higson 2000:58-68). National identity and national cinema are intrinsically linked. Elements in play include: a sense of belonging; a secure and shared identity; geopolitical consistency; and traditions, rituals, and consistent modes of discourse (Higson 2000:58). Higson originally contended that "national cinemas were the product of a tension between 'home' and 'away', between the identification of the homely and the assumption that it is quite distinct from what happens elsewhere" (Higson 2000:60). Although Higson has reconsidered these concepts, this 1989 definition may well remain relevant for a once-isolated Japan, our most-Japanese of directors, and his tale of a family in flux, where home is, indeed, different from away. In later writings, Higson noted weaknesses in those contentions, which assume that national identity and tradition are formed and fixed (Higson 2000:60). Rather, they are constantly in flux.

Will Higbee and Song Hwee Lim, in theorising cinema as a transnational, industrial art form, consider the intersection of global and local, national and transnational. ${ }^{3}$ Arguing in favour of a more critical form of transnationalism to better understand this shared space, the two see momentum shifting from a binary national/transnational approach (Higbee and Lim 2010:17). Given things are seldom clear cut, this reshaping seems sensible. They also suggest that discourse should extend beyond the theoretical, to examine the "concrete-specific" so that power dynamics can be explored and exposed (Higbee and Lim 2010:10). Mette Hjort notes that some films are initially produced and oriented in national terms, though can evolve transnationally (Hjort 2010:14). This is germane to Tokyo Story. Delving more deeply into transnational trajectories, Hjort proposes assessing the transnationality of a film using criteria such as production, distribution, reception, and the cinematic works themselves (Hjort 2010:13). Hjort sets out nine categories of transnationalism, ${ }^{4}$ then backfills the detail. Among Hjort's categories, Ozu sits within several, though is perhaps best described as modernising transnationalism, "which designates the confluence of a conception of cutting edge cinematic practice as essentially transnational with a concept of culture as a resource for modernization and recognition" (Hjort 2010:25).

Deborah Shaw notes that transnationalism evolves as an understanding develops that "cinema is part of the process of cultural exchange" (Shaw 2013:48). It is an assertion this dissertation supports. She asks: "Does the term refer to production, distribution and exhibition, themes explored, aesthetics, nationalities of cast and crew, audience reception, or a range of these?" (Shaw 2013:47). The answer, for the purposes of this paper, is a range. Shaw defines transnationalism via 15 groupings, across which a film can easily straddle. ${ }^{5}$ Such is the case with Tokyo Story. Perhaps the most relevant of Shaw's groupings is that described as the transnational mode of narration, which "relates to the content of films and the cinematic storytelling devices used that make them accessible to audiences in many parts of the world" (Shaw 2013:54). All films are, to a degree, national, Shaw contends, finding links between national identities and cinematic storytelling (Shaw 2013:65). There are clear associations to Tokyo Story, where $\mathrm{Ozu}$ has married national identity with a very human yarn to create broad appeal. As one reviewer

3 https://humanities.exeter.ac.uk/modernlanguages/staff/higbee/research/ Accessed August 28, 2018.

4 See Hjort, Mette, 2010. "On the Plurality of Cinematic Transnationalism”. In World Cinemas, Transnational Perspectives.

5 See Shaw, Deborah, 2013. “Deconstructing and Reconstructing 'Transnational Cinema”. In Contemporary Hispanic Cinema: Interrogating Transnationalism in Spanish and Latin American Film. 
noted in 1965 in Britain, Tokyo Story was the "best kind of evidence there is that, to be international, art must first be truly national” (Monthly Film Bulletin 1965:73).

Having considered national and transnational cinematic discourse, several observations can be made. Ozu directed home drama for a home audience. He was conscious of the unique characteristics of Japanese cinema and equally savvy about western narratives and the power of storytelling. There can be little doubt that Tokyo Story, though made for Japan, evolved to occupy a transnational space. Indeed, scholars compare Ozu to great poets, sculptors and painters, "For like theirs, Ozu's oeuvre is not merely an individual achievement but, more significantly, that of an historical and national collectivity" (Burch 1979:185). It is time to depart the theoretical, as Higbee and Lim suggested (Higbee and Lim 2010:10), and to consider, in a more practical sense, Tokyo Story's journey.

\section{Outreach begins}

Change came quickly to postwar Japan; sovereignty was reclaimed in 1952 and an American-crafted constitution created a disarmed, democratic and more modern state (Dower 1999:28-29). Tokyo joined the International Monetary Fund that same year. ${ }^{6}$ In 1953, Richard Nixon noted the value of cultural outreach in rebuilding international bridges (Nixon 1953:363-64). In keeping with that outreach, Japan entered into the General Agreement on Tariffs and Trade in 1955. ${ }^{7}$ In 1956, it joined the United Nations, and an economic white paper declared "the postwar period is over", a phrase that became a rallying cry for a renewing nation. ${ }^{8}$ And 1957 saw Nobusuke Kishi, who was prime minister and foreign affairs minister concurrently, describing diplomacy as "opening wide in all directions” (Kishi 1957:553).

Away from foreign policy, Nixon's reflections on the power of cultural outreach were apposite. In 1951, Akira Kurosawa's film Rashomon (1950) won the Golden Lion, the Venice Film Festival's top prize; the following year it was honoured as best foreign-language film by the American Academy of Motion Picture Arts and Sciences. ${ }^{9}$ The Japan Motion Picture Almanac noted in 1957 that Rashomon's "unexpected success opened a new vista for export" and offered the industry a "bright hope” (Japan Motion Picture Almanac 1957:23). Rashomon was screened at New York's little Carnegie Theatre and art theatres across America (Japan Motion Picture Almanac 1957:23). Soon after, Teinosuke Kinugasa's Gate of Hell (1953), which was Japan's first Eastman colour film, earned a Grand Prix at the 1954 Cannes Film Festival (Japan Motion Picture Almanac 1957:23). This was followed by a record run of 46 weeks at New York's Guild Theatre (Japan Motion Picture Almanac 1957:23). Four more films - Life of Oharu (Kenji Mizoguchi, 1952), Ugetsu Monogatari (Mizoguchi, 1953), Seven Samurai (Kurosawa, 1954) and Sansho Dayu (Mizoguchi, 1954) - received awards in the three years following Rashomon's success (Japan Motion Picture Almanac 1957:23). These were jidaigeki: lush, exotic period dramas featuring curious costumes and uniquely coiffed players, firmly fixed in historical themes. "It may well be said that the high standard of the Japanese motion picture is maintained chiefly through the indefatigable efforts on the part of the directors," industry insider Ichiro Ueno wrote in 1954 (Ueno 1954:64).

Rashomon's acclaim created a hunger. Some critics compared film festivals to the Olympics, urging entries "with no other idea than to win for the glory of the motherland. Each failure to win a festival prize

\footnotetext{
6 http://www.meti.go.jp/english/aboutmeti/data/ahistory.html Accessed August 2, 2018.

7 http://www.meti.go.jp/english/aboutmeti/data/ahistory.html Accessed August 2, 2018.

8 http://www.meti.go.jp/english/aboutmeti/data/ahistory.html Accessed August 2, 2018.

9 http://www.oscars.org/oscars/ceremonies/1952/memorable-moments Accessed August 21, 2018.
} 
was regarded as a national disaster" (Anderson and Richie 1982:233). These endeavours were the result of persistent campaigns by trade associations and the like, which were advised by the foreign ministry and ministry of international trade and industry, according to Teresa Becker (no date; cited in Davis 1996:34). Indeed, producers and distributors created films in the 1950s targeted for export to the festival and arthouse circuits (Desser 1997:2). It was the commodification of national cinema (Davis 1996:36), its appropriation by trade bodies and government policymakers for transnational purpose.

The year 1955 saw Japanese government involvement in this process. A Film Council, created by Cabinet decree, tackled "all matters" related to the industry, including import, export, exhibition and "the handling of motion pictures from the standpoint of educational and other values" (Ireton 1955:1). The Film Daily, self-ascribed "newspaper of motion pictures" and published in New York, reported that the council would unite industry interests, which had been "scattered" among ministries, including foreign, finance, education, welfare, and international trade and industry (Ireton 1955:1). With cinema's economic and cultural potential now a policy focus, that Film Council created another body, a government-licensed "public relations organisation" named the Association for the Diffusion of Japanese Films Abroad, Inc (Japanese Films 1958:1). Registered in 1957, and also known as UniJapan Film, its mandate was to promote overseas interest in Japanese cinema and "through the medium of the screen contribute towards international friendship and understanding” (Japanese Films 1958:1). Industry leaders seemed happy to toe the government line. Shochiku's Kido captured media attention on an international promotional tour. In October 1955, The Film Daily, noting that Japan had "only recently completed World War II reconstruction”, quoted Kido saying that Shochiku sought to increase its foreign market share, especially in the US (Loewenthal 1955a:1). Influential British magazine Sight and Sound, meanwhile, summarising 1955's film highlights, noted encouraging signs in world cinema, including "tantalising reports from Japan” (Sight and Sound 1955-56:114).

Into a tried and tested offering of period drama emerged Tokyo Story. The understated film of the everyday, depicting the difficulties of the Everyman, and made by the most Japanese of directors, it seemed an unlikely addition to exports focused on sword-wielding warriors and artful courtiers. Although made in 1953, Tokyo Story did not join the first wave of exports in the early 1950s. Those transnational honours instead fell to films such as Mizoguchi's Ugetsu Monogatari, Kinugasa's Gate of Hell, and Hiroshi Inagaki’s Samurai Trilogy (1954-56) (Desser 1997:2-3). “So why wasn’t Ozu’s film exported overseas," ponders Tadao Sato, the cinema critic and historian. Sato, aged 88, considered the question in an interview with this researcher in Kawasaki, Japan, on June 25, 2018, which was interpreted from Japanese into English by Yuki Ito. Shochiku's Kido "thought that Ozu's works would not be understood by foreigners", Sato said. Families sitting on the floor, around a low table, and eating food, represented the everyday, said Sato, so Japanese could appreciate Ozu, "but foreigners would not be able to. So that is why, I think, this film was not exported or introduced to international film festivals". On reflection "you would think that his film, the theme of his film, would be understood throughout the world".

The notion that Ozu's shomingeki films were constrained by genre is commonly held. Take, for example, Desser, who edited a collection of essays on Tokyo Story. He contends that western appreciation for Ozu's works did not emerge until the mid-1960s, after the director's films were presented at festivals, museums, and New York theatres. Suddenly was "revealed a director seemingly at odds with wandering swordsman and magnificently costumed women that defined” Japanese cinema (Desser 1997:3). In his writings, Sato notes that "Ozu has been considered the most Japanese, to the extent that his films were 
not even entered in international film festivals until near the end of his career" (Sato 1982:185). Jasper Sharp follows similar thinking, writing that Shochiku considered Ozu's films "too culturally specific for non-Japanese audiences" (Sharp 2011:195). Although noting that Tokyo Story garnered the Sutherland prize in London in 1958, Sharp contends that fame did not come until 1963, through a retrospective of Ozu's work at the Berlin Film Festival (Sharp 2011:195).

That timeline of acclaim, however, is not entirely accurate. This dissertation can reveal that, as early as 1955, three full years before Tokyo Story won accolades in London and eight years before the Berlin retrospective, the film was being lauded for international showings in private correspondence (Richie 1955a:1-4). And even earlier than that, possibly as far back as 1948, Ozu as a director was being promoted by savvy Japanese production executives with an intimate knowledge of the industry and an international reach (Richie 2004:309). These were Ozu's patrons, the influentials who saw the merit in his auteurism.

At the centre was American Donald Richie, who arrived in occupied Japan on January 1, 1947, as a typist within the US administration, secured "more congenial employment" at the Pacific Stars and Stripes, became film critic at the Japan Times, and made Japanese cinema his life's work (Lowitz 2004:IX). Movies offered Richie "a glimpse into an entirely Japanese world”, writes his friend, Ian Buruma (Buruma 2018:71). With his newspaper reviews and extensive writings, Richie "put Japanese cinema on the Western map” (Buruma 2018:170). Joining Richie in the patron's circle was Kashiko Kawakita, who, with film distributor husband Nagamasa Kawakita, circulated effectively overseas. Kashiko Kawakita held sway at many an international gathering. On the perimeter were scholars in the US, particularly Harold Leonard and Earl Miner at the University of California in Los Angeles, and lovers of both Japan and its cinema in Europe, notably John Gillett and Derek Prouse, both associated with the British Film Institute (BFI hereafter) and its National Film Theatre (NFT hereafter).

Remarkable letters dated November 22, 1955, and December 16, 1955, indicate that Richie had become a lynchpin for western cinephiles (Richie 1955a:1-4; Richie 1955b:1-2). These letters between Richie and Harold Leonard, of the theatre arts faculty at the University of California in Los Angeles (UCLA), show them collaborating on what would become a landmark screening of Japanese cinema in the US (Richie 1955a:1-4; Richie 1955b:1-2). Richie went on to become a world expert in the field. Leonard died of cancer at the age of 47 , just months after the programme was screened. ${ }^{10}$

"You mention a series of six pictures," Richie writes to Leonard in the correspondence (Richie 1955a:3), held at the Charles E. Young Research Library in Los Angeles and obtained with the assistance of UCLA's special collections team. "I should strongly suggest the following; these I know you can get," Richie continues, listing: Tokyo Monogatari; Mugi Bue [sic] (1955); Shiosai (1954); Nijushi no Hitomi (1954); Ikiru (1952); Entotsu no Mieru Basho (1953) (Richie 1955a:3). Richie further notes that such a screening would give Leonard the following directors: Ozu, Shirō Toyoda, Senkichi Taniguchi, Keisuke Kinoshita, Kurosawa and Heinosuke Gosho (Richie 1955a:3). Richie also discussed distribution, telling Leonard he was writing to three of the top companies: Daiei, Toho and Shintoho (Richie 1955a:1). "I am suggesting that they send you material direct rather than have you attempt to obtain it through their West Coast branch offices which are often slow in their operation" (Richie 1955a:1). Richie noted that "the film industry here is so anxious for foreign bookings that they overlook no opportunity” (Richie 1955a:1).

Richie's letters detail an industry evolving at a breakneck pace. He notes the difficulty in obtaining

10 https://oac.cdlib.org/findaid/ark:/13030/c8p84dzh/ Accessed August 24, 2018. 
older Japanese films. "The prints are hardly ever recalled to the studio, instead they pass from booking to booking until they literally fall apart” (Richie 1955a:1). Richie also remarks on the accessibility of Japanese cinema. While "sub-titling is of very recent vintage in Japan", he writes that Shochiku "is at present sub-titling everyone of its products and hope to let them loose in America” (Richie 1955a:1-2). In America, meanwhile, subtitling was also a consideration. The Film Daily noted in October 1955 that Japanese and German films were expected to make a strong foothold in the US in 1956, adding that the "advancement of dubbing techniques here will result in quicker acceptance of imported product" (Loewenthal 1955b:1). Tadao Sato, in his interview for this dissertation, said he believed Richie was behind early Japanese subtitling efforts. Richie's inability to read Chinese or Japanese script (Buruma 2018:17) meant he would have needed assistance. "I assume that there were lots of foreign people involved in this subtitling activity and I think he played a role of supervising the subtitles once they were done," said Sato. British film critic Dilys Powell, who was instrumental in establishing the London Film Festival, also mentioned subtitles in highlighting the "appalling difficulties" in obtaining foreign films (Powell 1958:435). Writing in 1958, Powell noted that: "The new film by an admired director will not be ready in time. The interesting experimental piece has not yet been sub-titled: it will be too late" (Powell 1958:435). Such challenges, however, did not impede success. Sato recalled the expansionist nature of a lucrative sector. "It was the golden age of the film industry, so revenue-wise it was very profitable," said Sato, who chuckled in recalling that some studios were so flush their executives "kept money in boxes and put their foot on top of the boxes because they had too [much] money coming in".

In a departure from the traditional jidaigeki exports, five contemporary films were shown in California in March and April 1956. The screenings were supported by UCLA, along with the Japanese Consul General in Los Angeles and the Motion Picture Association of Japan (Miner 1956:354), an organisation that had the blessing of Tokyo's Ministry of International Trade and Industry.11 Leonard watched upwards of 100 films in making the selection (Miner 1956:354). Chosen were: Gosho's An Inn at Osaka (Osaka no Yado, 1954); Mikio Naruse's The Echo (Yama no Oto, 1954); and three of Richie's original suggestions - Toyoda's Wheat Whistle (Mugi-Bue), Kurosawa's Ikiru, and Ozu's Tokyo Story, which was screened under its alternative title, Their First Trip to Tokyo (Miner 1956:355).

Richie noted a warm reception for Tokyo Story. "It was highly successful, and his [Ozu's] films are eagerly awaited on the Hawaiian and west coast circuits which Shochiku services" (Anderson and Richie 1982:359). A savvy Shochiku under Kido had established a Los Angeles branch office in 1953; by 1955, it led its competitors "in both the number of films it exports and the revenue obtained from overseas distribution” (Loewenthal 1955a:1). "If you can sell films to America, you can sell them anywhere," Kido declared (Loewenthal 1955a:1). International earnings from exports in 1953 stood at $\$ 1,200,000$, dipped to $\$ 884,000$ in 1955 , and then rose to $\$ 1,259,000$ in 1956 , to $\$ 1,328,000$ in 1957 , and to $\$ 1,722,000$ in 1958 , according to Eiga Nenkan (1960; as cited in Tezuka 2012:51). The UCLA showings were heralded as a first opportunity for foreign audiences to see Japanese film "as it really is" (The Japan Times 1956:4), presumably in reference to the home dramas that were screened. Others noted Tokyo Story's merits. "The film is not one to call great, but it has the satisfying excellence of art of integrity and beauty," wrote Earl Miner, an English professor at UCLA:

Although these films are worthy of attention in themselves, their showing in Los Angeles has had a

11 http://www.eiren.org/aboutus_e/index.html Accessed August 6, 2018. 
kind of collective significance which ought not to go unmentioned. The Japanese Film Series was the first such event in this country, perhaps anywhere in the world: the first coherently chosen body of Japanese films, the first group shown to an audience not primarily of Japanese descent, and the first group of modern films on modern Japanese life to receive such attention in this country. It was, then, a historical event. (Miner 1956:363)

It is worth spending a moment with Miner, a Japanese studies undergraduate who later specialised in literature. Although his connection to Leonard is unclear, his motivations are not. In 1958, Miner, who had "wartime training", (Miner 1956:354) explained his wish "to dispel certain illusions about Japan, because I can remember some with embarrassment the misconceptions in my mind when I first set foot there" (Miner 1958:ix). One of the "falsest and most unfair" notions of Japan is the "spiteful image of a nation of barbarians" (Miner 1958:x). He calls the Japanese "human beings with virtues and faults, aspirations and needs, more like to than different from our own" (Miner 1958:x). With Japanese film ascending, Miner saw it achieving "fruitful contact with our culture" (Miner 1958:277). It is no surprise, then, that Miner appreciated Tokyo Story's context, or that Japan recognised Miner's commitment to Japanese literature by awarding him the Order of the Rising Sun (Quiñones 2004).

The Japanese government, at least one of its endorsed organisations, and academics had seen the merits of exporting a more realistic genre (the government role will be considered in more detail later). Who else was involved? Miner writes that “... certain Japanese film companies and some Americans have given considerable thought to introducing Japanese films of a very different nature” (Miner 1956:354). Richie was surely one of them. Tokyo Story was a Richie favourite; he described the film in a 2004 interview as "impeccable" (Mansfield 2013). "Aesthetically, it is one of the most balanced structures in the history of cinema. Technically, it is made of nothing at all. It is an exercise in economy and conciseness" (Mansfield 2013). Sato, who began reviewing cinema in 1952, credits Richie almost single-handedly for Ozu's rise, noting in a 2013 newspaper article the American's determination to see Tokyo Story succeed in the face of studio reluctance to export the film:

The production companies didn't listen, but Richie didn't give up. He took it upon himself to introduce Ozu's films to international audiences at every available opportunity. He was often invited to curate screenings at foreign festivals, and he would include Ozu's films. The result of those efforts was that very gradually the quality of Ozu's work became known to the world. Ozu's reputation grew and grew until "Tokyo Story" began turning up on "Best Film of All Time" rankings. (Sato 2013)

"Donald much preferred the movies of Ozu Yasujirō," with their quiet, humanistic fatalism, writes Buruma (Buruma 2018:49). Richie's inclination towards Ozu has been noted elsewhere. Boel Ulfsdotter, in her $\mathrm{PhD}$ dissertation, scrutinized Richie's writing, finding he showed a preference for Ozu, Mizoguchi, Kurosawa, Gosho and Kon Ichikawa (Ulfsdotter 2008:133). It is possible his early writings "should be understood as promoting the films by these directors. Whether this was done on his own initiative I cannot say" (Ulfsdotter 2008:133). Noting his close contacts within cinema, Ulfsdotter says Richie's "persistent elevation of particular Japanese directors may simply have been a case of focused film product placement", while questioning "to what extent" his books on cinema were commissioned by the industry itself (Ulfsdotter 2008:133). This "is not known," though "judging from their contents”, Richie "had a unique and direct access to people and documentation” (Ulfsdotter 2008:228). 
So Ozu's breakthrough film was discussed in 1955 and showcased in America in 1956. And Richie was hugely influential. Richie was introduced to Ozu as a filmmaker long before that, possibly as early as 1948, in a conversation with Kashiko Kawakita. Writing in 1993, at the time of her death, Richie recalled their first encounter:

Very early, the first - 1948 or so - she is young and beautiful, and I am twenty-four and sitting on the tatami in her old Kojimachi house, and she smiles because I am interested in films ... and perhaps she asks if I have ever heard of Ozu. I seem to think she did, but I no longer know.” (Richie 2004:309)

As early as 1948, with Richie a budding film buff, Kashiko Kawakita was quietly advancing Ozu.

Richie propels the tale to Europe with a postscript to his November 1955 letter. Noting interest in London for a "special season of Japanese films", Richie connects Leonard with the BFI's Gavin Lambert (Richie 1955a:4), who was then editor of Sight and Sound, and went on to write books and screenplays. Richie gives Leonard a postal address and urges: "I'm sure they would like to hear from you, particularly in reference to your proposed festival" (Richie 1955a:4). This is one of the earliest references this researcher could uncover to what would become a landmark season of Japanese cinema at London's NFT. Called $A$ Light in the Japanese Window, the NFT screened 15 Japanese films, including Ozu's masterpiece, between October 28, 1957, and January 19, 1958 (BFI 1957). Tokyo Story would, soon after, win its first international prize. The decision-making around this crucial win will be examined in further detail. For now, it is worth noting Richie's sway in the genre of film being considered from Japan, his outreach to studios on procurement and distribution, and his activity in assessing audience response. Also significant is Richie's nurturing of a network of prominent, savvy individuals with access to showings and industry press. As Sato said in his interview: "Some people in America and Europe, they were friends of Richie and his friends. This community gradually spread, little by little."

Before emerging in London, however, Tokyo Story surfaced in a more unlikely setting: Ireland's Cork International Film Festival. Businessman Dermot H. Breen founded the festival in 1956 with the backing of the International Film Producers' Association, however, "between agreement and participation there was a gap” (Manning, date unknown; Sweeney 1956:418). The second festival, held in May 1957, presented 50 films from 15 nations (Brennan 2015; Walsh 1957:467). Notable was "the slow-moving but tender Japanese contribution, Their First Trip to Tokyo" (Walsh 1957:469). John Gillett, a consultant programmer at the BFI, who worked closely with Kashiko Kawakita (Kawakita 1990), reviewed the first Cork festival for Sight and Sound, (Gillett 1956:5-6) though there is nothing to indicate he reviewed the second. While crediting Breen with its "social and popular" success, Gillett found the film programming "fell well below an acceptable international standard" (Gillett 1956:5-6). The 1959 Japanese Film almanac references Tokyo Story in Cork in 1957 and indicates it received the undefined "Selection Award" (Japanese Films 1959:84). The almanac details the scope of industry outreach from 1951 through 1958, with some 200 entries of various films, very few of them repeat, into a range of festivals and screenings, from Australia to Canada, Tashkent to Uruguay to India (Japanese Films 1959:78-88). It is difficult to know just how Ozu's film came to be screened in Ireland in 1957. Perhaps personal factors were in play, with Gillett on the ground in Cork a year earlier and as his friend, film maven and Ozu supporter Kashiko Kawakita worked the rounds in a closely knit European cinema community. 
Wife and husband with power and purpose

Madame Kawakita, as she was known, was at the centre of the European cinema scene. Arriving in London in 1956, she plugged quickly into the UK capital's circuit too (Robinson 1987:25). In that same year, in a sign of her stature both at home and abroad, she was asked by the culture section of the Japanese embassy in London to accept an award on behalf of director Kaneto Shindo, whose film Children of Hiroshima (1952, Genbaku no Ko) was to receive British Film Academy recognition (1956; as cited in Kawakita 2017:268, translation Sawako Irie). Black-and-white newsreel footage viewed at Tokyo's Kawakita Memorial Film Institute in June 2018 shows a kimono-clad Kashiko on stage at London's Odeon Leicester Square on March 1, 1956, speaking in English to accept the honour on behalf of the Japanese film industry (British World News 1956). Kawakita served, over several years, on more than 20 international festival juries (Gillett 1994:9). Developing friendships with cinephiles Lotte Eisner and Henri Langlois of the French film body Cinémathèque Française, and Gene Moskowitz, the Paris correspondent for Variety, she helped in 1957 to plan a Japanese Film Week in Paris (Robinson 1987:255). Moskowitz wrote a steady stream of at least 73 Japanese film reviews between 1951 and 1975 (Ulfsdotter 2008:136), begging the question: Was Kashiko the influencer at work? She curated the Japanese screenings in Paris soon after working in London with NFT programmer Derek Prouse on the BFI's own special season (Ulfsdotter 2008:84; Roud 1983:90-91).

"She was the lady in purple ... she always wore the kimono," recalls Leslie Hardcastle, who joined the BFI in 1947 and remained there some 45 years. ${ }^{12}$ He was prominent in both the BFI and NFT, became NFT controller, and, in 1975, was awarded the Order of the British Empire for services to film (BFI 2002). One of the few people still alive who was integral, from a British perspective, to the golden age of Japanese cinema, Hardcastle, aged 92, made the comments in an interview conducted by this researcher in London on May 9, 2018. If Richie was the US lynchpin, Kashiko Kawakita was the European hub. "She had a fantastic brain" and was shrewd in business matters, Hardcastle said. She was "regal" and displayed a "Japanese style", hosting receptions and giving gifts, making her popular on the European circuit. "At the Cannes Film Festival, everybody wanted to go to the Japanese reception," Hardcastle recalls. Fluent in English, Russian, French, Italian, Spanish and the "single most significant figure in shaping the taste of westerners toward Japan through its remarkable cinema”, Kashiko took the most important Japanese films for critical viewing abroad (Mellen 1975:59-61). Versed in cinematic narratives, experienced in distribution, influential on film juries, networked with film critics, and popular with European players, she was surely Japan's greatest cultural ambassador.

Kashiko and husband Nagamasa Kawakita operated through his distribution company, Towa Shoji Goshi Kaisha (Gillett 1994:9). Towa's remit extended well beyond the commercial. Impressed by the socio-political importance of the media (Robinson 1987:254) and sensitive to western stereotypes of Japan, Nagamasa, who became a "legendary figure within Japanese cinema", (Buruma 2018:74) fretted about his nation's misrepresentation in film (Standish 2005:140). Having seen a production of Madame Butterfly in Hamburg in the 1920s, Nagamasa was irked by skewed cultural signifiers, considering them a "national humiliation" (Tezuka 2012:47-48). Thereafter he became active in "constructing differences in relation to the West as a form of national self-affirmation" (Tezuka 2012:47-48). With a "strong need to promote international understanding" (Tezuka 2012:47), Towa, "set itself the cultural tasks of making

12 Personal communication. Leslie Hardcastle consented to be interviewed and quoted. See Appendix B. 
Japanese cinema known and valued abroad" (Mellen 1975:59).

The Kawakitas undertook their first cinematic buying trip to Europe in 1932, repeating the journey five times until 1938 (Robinson 1987:254). Kashiko handled artistic decisions and Nagamasa the negotiations (Robinson 1987:254). The 1938 journey would be their last for 13 years (Robinson 1987:255). Having been a student in China and Germany, Nagamasa had a "deep knowledge and understanding of foreign motion pictures" (Japan Motion Picture Almanac 1957), which the government utilized in wartime. Film import was prohibited, so Towa closed its office and Nagamasa went to Shanghai to head a group of Japanese-controlled studios and cinemas (Robinson 1987:255), creating propaganda aimed at the Chinese (High 2003:335). He was also a member of the Home Ministry's Motion Picture Committee and director of the Japan Motion Picture Association and the Japan Motion Picture Corporation in those conflict years (Japan Motion Picture Almanac 1957). From the start of the Sino-Japanese War in 1937, until 1945, the industry was thrust under the control of the home affairs ministry, pre-production scripts were censored, and filmmakers were forced to work within an ironclad framework (Sato 1982:100). After surrender, Nagamasa was sanctioned as a war criminal and banned from the industry (Tezuka 2012:47) and was then "de-purged" in 1951 (Japan Motion Picture Almanac 1957). Decorated by the French government in 1953 for his contributions to the "promotion of cultural relations between Japan and France”, Nagamasa was also director of film distributor Toho Co., Ltd. and chairman of the Industrial Rationalization Council of the Ministry of International Trade and Industry (Japan Motion Picture Almanac 1957), a government body that tackled postwar economic challenges. There were clear linkages between this power couple, a desire to promote positive images of Japan, their influence in exhibitions, screenings and juries in Europe, an understanding of the persuasive power of cultural exports, domination of distribution, and involvement with Japanese government postwar policy.

Richie writes that the same Japanese who had produced wartime military pictures quickly became "among the loudest tub-thumpers for democracy" (Anderson and Richie 1982:164). "These boosters for even further democratization, in particular wartime film leaders from Toho", changed their tune with "fluent facility" and lead the charge for greater westernization (Anderson and Richie 1982:164). Peter B. High, in The Imperial Screen, agrees that in "the immediate postwar years, many of the most ardent makers of wartime propaganda films were back at work this time making pro-democracy pictures ..." (High 2003:510). Richie's tub-thumper remark may well have been a reference to Nagamasa. Richie knew the Kawakitas well; as we saw earlier, Richie first met Kashiko sometime around 1948. She sponsored his application for permanent residency in Japan, introducing Richie to the works of $\mathrm{Ozu}$, and to the director himself (Richie 2004:309-10). Richie recalls how Kashiko took him to Shochiku to meet Ozu, "who drinks tea with us and seems amused at my reverent gaze" (Richie 2004:309).

Ozu's own journals show him socializing with the Kawakitas in seaside Kamakura, where they were neighbours (Ozu 1996, translation author's own). An entry for January 3, 1953, the year Tokyo Story was written and filmed, detailed "the first meeting of the year" of what Ozu called the "Kamakura Circle", those involved in cinema, the arts and literature, and a group that included the Kawakitas; there are two other references to this social network over just a few months (Ozu 1996:321, 323, 342; translation author's own). There can be little doubt that Ozu and the Kawakitas were friends, as were Kashiko and Richie.

Kashiko Kawakita left an impression wherever she went. She identified the power brokers in 1950s London, among them BFI director James Quinn, Dilys Powell, the socialite, film reviewer, and a force 
behind the inaugural London Film Festival, Prouse, the BFI programmer who also reviewed films with Powell for the Sunday Times (BFI 1957-58) and Gillett, who became associated with the BFI in 1952 and remained there 44 years (Hardcastle 1995). All were influential as the BFI planned and staged the first 1957 film festival and a season of Japanese cinema that followed. Kashiko was instrumental in curating that season, called A Light in the Japanese Window, with the BFI offering her "warmest thanks" and noting that she had become "a valued friend" (BFI 1957).

While in London, Kashiko formed valuable alliances. She described Powell as a powerhouse within cinema circles, where no man could equal her as a reviewer (1961; cited in Armendáriz-Hernández and González-López 2017:50). Speaking in 1961 at a roundtable on women in postwar Japanese cinema, in association with Kinema Junpo, Kashiko recalls Powell, aged “55 or 56”, as a "very beautiful woman” (1961; cited in Armendáriz-Hernández and González-López 2017:48). "Powell writes her reviews from a feminine perspective. Sometimes she is prejudiced and subjective ... and that probably clicks with women," Kashiko said (1961; cited in Armendáriz-Hernández and González-López 2017:48). Powell clicked, it seemed, with all manner of people. She hosted the dinner party where the BFI's Quinn, programmer and reviewer Prouse, and her husband Leonard Russell, literary editor at the Sunday Times, conceptualised the London Film Festival. Writing in 1981, to mark the festival's twenty-fifth anniversary, Prouse recalls the evening, and how he "raised the suggestion of a London Film Festival, a Festival of Festivals" (BFIa). Once the festival became reality, Powell gathered elites at her London home on the programme's inaugural evening. In a sign of her celebrity sway, Kashiko Kawakita was invited. In fact, Powell used her as a draw in an invitation penned on October 9, 1957, which appeared aimed at actress Vivien Leigh and then-husband Laurence Olivier:

On Thursday, October 17, the evening of the opening to the general public of the London Film Festival, which you may know "The Sunday Times" is presenting at the National Film Theatre, my husband and I are giving a small supper party in our own house. I wonder if there is any chance that you and Sir Laurence would join us? ... We are hoping that Akira Kurosawa, director of the Japanese "Macbeth film which opens the programme, will be with us, together with Mrs Kawakita, wife of the distributor; we are asking also a few of the other distinguished foreigners -- directors and players - who are coming to London for the Festival ... Leonard and I should love it if you could manage it: eleven p.m., this address. (BFI 1957-58)

“Don’t forget, Madame Kawakita is the link," Hardcastle reminded in his interview. Kashiko fostered a working relationship with programmer Gillett, reflected in letters among Gillett's papers in the BFI archives, including an undated New Year's greeting card (BFIb; BFIc). In 1990 correspondence with Gillett about screenings, an ailing Kashiko apologises for a tardy reply, signing off: "Please forgive my laziness, with much love” (BFIc). There is no doubt the two were collegial. Further developing this dissertation's assertion of a linked network of Ozu supporters, Hardcastle recalls that Gillett worked closely with Richie, adding: "John Gillett fell in love with Japan” and within the BFI "Japan belonged to him”. This connection would prove pivotal.

Tokyo Story's 1958 Sutherland award win is reasonably well documented; it is the moment considered in cinematic scholarship to be Ozu's breakthrough in the west. The prize was awarded to the most imaginative and original film showcased at London's NFT in a given year. Tokyo Story was screened in London from November 15-17, 1957, as part of the Light in the Japanese Window series, in which Kashiko 
was so persuasive (BFI 1957). Unclear in current scholarly writing, however, is exactly why Ozu's film won (the question that inspired this dissertation). With the master craftsman directing, the film was undoubtedly compelling. But there is more to the story. The decision-making was heavily influenced by Gillett, with his love of Japan and his connection to the Kawakitas, and by concerns for Ozu's domestic status in the late 1950s, where the cinematic landscape was in flux. Hardcastle, in his interview, provided the context:

I remember that when we ... awarded Ozu the Duke of Sutherland award, the BFI award ... there was a great fight going on but there was a delay because John Gillett had actually said that we must, not only because it was a great film, we must do it for Ozu because he's not flourishing at this moment in his own country ... it'll do a great deal of good for him if he wins the BFI award for Tokyo Story. And I remember that argument ... I do know he won that argument.

Writing Gillett's obituary, Hardcastle noted that the BFI programmer's "championing of the Japanese director Yasujirō Ozu was crucial to his obtaining funding for his films in Japan at a critical time in his career" (Hardcastle 1995). Gillett himself makes reference to Ozu's domestic difficulties in a 1976 BFI pamphlet he co-edited. Viewed at the Kawakita Memorial Film Institute library in Tokyo, this Ozu anthology indicates in an editors' footnote:

It is worth adding that several times after the war Ozu's stock was very low in Japanese film circles (he was accused of being conservative and out-of-date) and it was partly due to British and American critical writings on his career, which vastly encouraged him, that his work was eventually re-evaluated by Japanese critics and the film industry, who then decided that Ozu was not the 'unexportable' figure they had once assumed. - Editors (BFI 1976:2)

In Japan, by 1957, younger cinema-goers were far more interested in rising new stars of the era, among them Nikkatsu studio heartthrob Yujiro Ishihara and the taiyozoku genre of cinema, with its postwar disillusioned youth, than in the wistful old men of Ozu's shomingeki films (Gibbs 2012:48; Raine 2005). "Youth was a global problem in the mid-1950s, in literature, journalism, and film. The cultural old guard was in retreat,” Michael Raine explains (Raine 2005). Ishihara's appeal was at its peak in 1957 (Gibbs 2012:48). Japanese film societies struggled to support "famous films from the period, notably Ozu's Tokyo monogatari" (Gibbs 2012:29). Its "atmosphere of post-defeat stoicism" was "not exactly" what young film society members wanted to see (Gibbs 2012:29). Sato noted in Currents in Japanese Cinema that Ozu's postwar films "tend to lack social relevance because his affluent households were isolated from the disturbing currents occurring outside it" (Sato 1982:142). Woojeong Joo also highlights the chasm between the home dramas championed by Shochiku and the real world, suggesting audiences were growing "weary" of the genre (Joo 2017:194). "Ozu's personal attitude towards the new 'post-Occupation generation' seems not necessarily positive,” Joo writes (Joo 2017:194). Although the director did not outright reject the taiyozoku phenomenon, he told an interviewer in 1958 that he felt more inclined towards the elderly than the young (Joo 2017:194). Ozu's loyalty to a staid narrative has also been observed by Noël Burch, who describes the director's postwar filmmaking as the "history of a gradual fossilization" (Burch 1979:277). A reluctance to evolve may have put Ozu on the back foot at home just as the Sutherland prize was being considered. And so Ozu and Tokyo Story secured London acclaim. 
Cinema in this era was more than moving images. The Kawakitas knew it, and they were not alone. As Japanese government policy and panels targeted exports, and reviewers and programmers such as Richie and Leonard, Miner and Prouse and Gillett were persuaded by the shomingeki genre, studio executives also displayed an understanding of cinema's sway. Speaking in January 1958 at New York's Harvard Club during Japanese Film Week, which had the support of Japan's foreign affairs ministry, Shochiku's Kido reflected on the role of cinema in "contributing to world peace via better understanding between nations" (Motion Picture Daily 1958b:3). "Our industry has already demonstrated to the world how it is possible to reconcile differences and solve problems by friendly negotiation," Kido told his American audience (Motion Picture Daily 1958b:3). Those sentiments were echoed by the host nation. Eric Johnston, president of the Motion Picture Association of America, likewise stressed "the need for a unifying force in the world today, adding that such a force is the motion picture” (Motion Picture Daily 1958a:3). That same year saw further formal steps with the creation of the Federation of Japanese Film Industry, Inc (UniJapan Film Quarterly 1959:2). It marshalled the power of the Motion Picture Association of Japan, the Association for the Diffusion of Japanese Films Abroad, Inc., major production studios, and independent producers and exhibitors (UniJapan Film Quarterly January 1959:2). The president of this powerful new umbrella organisation: Shiro Kido. Among its directors: Nagamasa Kawakita (UniJapan Film Quarterly 1959:2).

Soft power is the ability to attract and persuade. That's how American political scientist Joseph Nye defined the term in his 1990 book Bound to Lead: The Changing Nature of American Power, and reiterated it in a 2017 podcast, calling it "the heart and soul of international politics". ${ }^{13}$ By acknowledging the power of cinema to build bridges in the immediate postwar world, Japanese politicians and policymakers displayed mastery of this concept well before it was formally articulated. With culturally sensitive film exports, embracing stories of the Everyman, or the shomingeki genre, industry producers, distributors and related power-brokers presented a universal, human, accessible and understandable image of Japan, one that was both attractive and persuasive. With their quiet but consistent promotion of Yasujirō Ozu's Tokyo Story, cultural ambassadors, film influentials, season programmers and cinematic reviewers embraced his humanist narrative. Audiences have, too. Sight and Sound's 2012 ranking of 100 directors sees Ozu on top ${ }^{14}$ for Tokyo Story, while its "50 greatest films of all time" ranks Tokyo Story third, two places higher than a 2002 poll, saying "this most Japanese tofu-maker" had refined his art to the point of perfection. 15

Conclusion: Influential storytelling at its finest

As Japan sought to reintegrate itself into a rapidly reordering postwar world, it needed to tell a new story of nation. This was no longer a land of weapons and warriors. The days of attack and invasion were done. With a new constitution and revised world view, the Japanese were now ordinary people, grappling with everyday issues. And as Japan sought to reconnect, the power of storytelling through cinema became a tool for outreach, in particular the narratives of humanist director Yasujirō Ozu. His passive, pensive Tokyo Story captured a family in flux, depicting shared dilemmas - maturing, ageing,

$13 \mathrm{https} / / /$ supchina.com/podcast/joseph-nye-jr-chinese-power-age-donald-trump/Accessed August 24, 2018.

14 https://www.bfi.org.uk/films-tv-people/sightandsoundpoll2012/directors\#main-content Accessed September 2, 2018.

15 https://www.bfi.org.uk/news/50-greatest-films-all-time Accessed August 24, 2018. 
dying. Although home drama, Ozu's universally appealing film evolved easily beyond national cinema, to transverse the national-transnational divide.

This dissertation shows that Tokyo Story was adopted and employed by an interlinked group of industry-savvy, culturally sensitive, and globally networked influentials who loved cinema, had an affinity for Japan, and were keen to position the nation anew. Occupation-era arrival Richie embraced Japanese cinema and worked tirelessly to promote Ozu through his writings, recommendations, and word of mouth. UCLA's Leonard had the courage to programme a ground-breaking shomingeki series. Literature professor and sometimes reviewer Miner sought to change ill-informed impressions of the Japanese. Reviewers Prouse and Powell envisioned London's festival of festivals - still among the world's best and, with celebrities, directors and industry insiders, feted its success. The BFI's Gillett was enamoured of Japan and argued for an award that would long be considered Ozu's western watershed. Industry insiders Kashiko and Nagamasa Kawakita moved fluidly on the world stage, influencing what films were seen, what prizes were given, and winning over decision-makers with their charm and cultural finesse, thereby creating positive images of their changing nation. Studio executive Shiro Kido, alongside industry and government policymakers, explored and exploited exports, cognisant of cinema's ability to attract and persuade.

This dissertation has: considered Ozu and his contemplative work; taken a snapshot of 1950s politics and the domestic film industry's position; captured the international cinema scene; and introduced those who took Tokyo Story to heart. It has presented evidence that Ozu and Tokyo Story were being quietly appreciated and promoted earlier than scholarly thinking currently contends. Furthermore, it has mapped out original theories as to how and why Tokyo Story secured 1958 acclaim.

Ozu and Tokyo Story helped to build bridges. This humanist director and his quiet, approachable work were a unique form of soft power, employed to reshape attitudes and sway thinking decades before the concept was formally articulated. Tokyo Story's gentle, unassuming, and enduring narrative proved better than any trade delegation or diplomatic emissary in evolving impressions. It was, and remains, masterful cinematic storytelling - thoughtful, simple, and at its influential finest. 
Appendix A: Interview with Tadao Sato

Verbal consent for this interview and its use by the author was given at the outset.

Interviewee: Tadao Sato, film critic, historian, author, currently president of the Institute of the Moving Image, Kawasaki, Japan

Interviewer: The author

Translator: The translator (Yuki Ito)

Interview time and date: June 25, 2018, 10am-11am

Location: Institute of the Moving Image, Kawasaki, Kanagawa prefecture, Japan

Additional information: This transcript has been lightly edited for clarity.

The Author: I am interested in the message Ozu was trying to send in his film. Sato-san you are an expert on Ozu so I would love to hear about that.

Tadao Sato: What I can do is to think: What was his message? The only message that can be understood is by Ozu himself.

Author: So, what do you think his message was with this kind of movie, a very gentle, thoughtful film about real people and real problems?

Sato: I think it's true, his style is gentle and compassionate. What is common in lots of his works is that people cannot stay together throughout life. As far as family is concerned, Ozu depicted family life in his work, but you cannot be loyal to family throughout life. Of course, he depicted love, and to be good to each other, but there is a limit to this love.

Author: Ozu was known as a humanist director who told a story people around the world can understand. It seems to me a kind of film that can change the way people view a country or a nation. And I think it's interesting that this film was exported overseas. Do you think this film has a special message for people in the 1950s?

Sato: I think that's a very subtle issue. I say this because his work was seen overseas just once while he was alive. I think if I remember correctly that must be around 1960 at the London Film Festival.

Sato: So why wasn't Ozu's film exported overseas? Around 1960, this was a time when films like masterworks by Kurosawa, Mizoguchi, Kinugusa were world-famous already. The company that was making his films was Shochiku, and the company president by the name of Shiro Kido, he thought that Ozu's works would not be understood by foreigners.

Sato: Why I say that, that Shiro Kido thought that this film would not be understood by foreigners, is that this film depicts people's ordinary lives, people sitting on tatami mat with trousers on the floor and at the low table, eating food all the time. This was an ordinary life of Japanese people. So Japanese people could appreciate this kind of film, but foreigners would not be able to appreciate this. So that is why I think this film was not exported or introduced to international film festivals. In the 1960s, somehow this film was introduced to the London Film Festival. I do not know who recommended this film. I think that perhaps an American by the name of Donald Richie actually recommended it. It's just imagining, because Donald Richie told many circles that it was him who actually recommended, and perhaps it might be him or his friend.

Sato: In retrospect you would think that his film, the theme of his film, would be understood throughout the world. But back then it was not only Shiro Kido, but many people in Japan who thought that Ozu's film would not be understood by foreign people.

Author: Does Sato-sensei think that Madame Kawakita had anything to do with introducing Ozu to the 
west?

Sato: It could have been Kawakita-san who recommended because she was a close friend of Ozu and ... she had a lot of foreign friends so she knew the mindset of foreigners so she could have thought that foreigners could understand Ozu's film.

Author: Did he [Sato-san] know Madame Kawakita personally?

Sato: I was in a very close relationship with her and she also helped my work. And she initiated an award called the Kawakita Award and she personally gave that award to me and my wife, that award.

Author: And Donald Richie, he [Sato-san] knew him well?

Sato: He was a close friend of mine.

Sato: Actually, I told Donald Richie that I was going to write about Ozu, he suggested I go to MOMA in New York to actually see the American movie that Ozu might have seen when he was young because they have the films, American old films at MOMA, so he actually wrote a letter to me to introduce me at MOMA. Not only when he was young, but this Tokyo Monogatari got the idea, the initial idea, from an American film called Make Way for Tomorrow.

Author: Yes, I've read that.

Author: Does Sato-sensei think that Kashiko Kawakita and Donald Richie were patrons of Ozu in terms of helping him breakthrough in the west?

Sato: I think these two people tried to become patrons for Ozu, they made efforts. But because of Kido Shiro ... I think they couldn't become patrons as much as they wanted to. But at around the time of Ozu's death his films started to be seen in America, in Germany, in Britain and in France.

Author: Does Sato-sensei [to translator Ito: talk maybe a bit about the government role in promoting film in the 1950s now], does he think the government had a policy of exporting certain kinds of films?

Sato: I think government never played a leading role in any of Japanese cinema. I think the government started to play a role once this Japanese cinema started to become famous. The people involved in the cinema industry also didn't want help from government because they had the experience from during the wartime. The Japanese government, it controlled cinema and had censorship on Japanese film work during [those] five years. It was a period when government decided what was a good film or not and because of this government role ... people in the cinema world remember their bitter experience during the war.

Sato: So, during the 1950s it was the golden age of the film industry, so revenue-wise it was very profitable. I think the government role comes into the cinema world when Rashomon received the Grand Prix at Venice and Japanese film started to become famous. So Japanese industry people started to think that Japanese films might do well if they were exported. Then came the government role in exporting, importing, in supporting, financing the film industry. So back then cinema industry people didn't need the support because they were lucrative, but they started asking for this support in 1960 .

Author: So, the movie studios were actually making quite a lot of money in the 1950s?

Sato: [He laughs with pleasure at the end of this bit] So I say not all companies were very profitable but there is this episode that it was too profitable, people kept money in boxes and put their foot on top of the boxes because they had too [much] money coming in.

Author: Does Sato-sensei [to translator Ito: this might be a good time to talk about subtitling, because if the studios had money, then they could afford to subtitle the films] ... so let's think about how subtitling got done. Does he know where the films were subtitled and why?

Sato: [Sato laughs halfway through this answer] I think Japanese were very good at subtitling because back in talkie cinema time in other countries it was the norm to have voice on top of these talking movies but in Japan, Japanese people prefer to have subtitling because they thought that foreigners speaking Japanese 
would seem awkward, so Japanese people liked the idea of subtitling. So, the idea of Japanese fans liking subtitling ended up with Japanese people being good at subtitling. At the time there were lots of Japanese people who were well-versed in English but when it comes to translating, it's another story, so I think here comes the influence of Donald Richie, I think maybe he might not have done the translation himself but I assume that there were lots of foreign people involved in this subtitling activity and I think he played a role of supervising the subtitles once it was done by many foreigners. He also supervised the style of speech and he saw in certain cases that this was, would not be taught ... but he did check the words.

Author: So, Donald Richie comes up again and again. What does Sato-sensei think was Donald Richie's motivation ... because he was so passionate about Japanese cinema, what was his motivation in exposing Japanese cinema to the west?

Sato: I think that's a question I would like to ask American people. For us, Donald Richie is a strange American, somewhat close to Japanese people. He did actually have lots of friends here, and I am one of these friends. What I remember about him is, he disliked America. He wasn't feeling well, when he was ill, he came back to Japan and his words were 'Oh, thank God I am back in Japan again'.

Sato: He describes Japanese cinema as shomin egia, as commoners, normal everyday life, he says that in film works like Ozu and Naruse these commoners' everyday lives are being depicted in the film.

Author: Does Sato-sensei think that Donald Richie was almost like an ambassador for Japanese cinema?

Sato: Yes, I quite agree with you. I think there were so many other people as well, but he is one of the most influential people in introducing Japanese film to the rest of the world.

Sato: He came to Japan as a member of the occupation army and right after he came to Japan he started all of a sudden to like Japanese cinema and I think ... he did the artwork for Stars and Stripes. He was a very strange man, liking Japanese cinema.

Author: It was quite unusual at that time for a westerner to be so passionate, so much in love. Does Satosensei think that Tokyo Story particularly would have changed the way western people saw Japanese after the war?

Sato: I must clarify this because I think his works were famous among some small communities like Donald Richie, but the rest of the regular journalists did not know about his works. His works started to be known after 10 years. So Ozu's masterworks were known to the rest of the world only in the 1960s.

Sato: [He laughs freely and repeatedly while answering] So Japan never sent Ozu's work to the rest of the world to make others appreciate film, so we never did this from our side. Some people in America and Europe they were friends of Richie and his friends, this community gradually spread little by little.

Sato: The comments that might be found common in foreign people who saw Ozu's film is: it's a fabulous film, but why is the main character ... acted by Setsuko Hara, who is not at all a beautiful lady. And the other thing is: why is the music so simple, like [that] which might be sung at a Japanese elementary school. Why is that? And I asked these two points to the American film critic ... he said: Well maybe she, Setsuko Hara, she may not be a beautiful lady but why should Ozu's film need a beauty, it's depicting just ordinary people.

Sato: He said it's fine because it's a domestic film.

Author: But I think Setsuko Hara was very beautiful.

Sato: [He chuckles again in this answer] So that's when I recognised that there are several types of prejudices among thinking which one is the beauty. There is a certain pattern, who is beautiful and who is not. For Japanese we think that Setsuko Hara is a very typical western beauty.

Author: OK, that's interesting.

Sato: Back to your question.

Author: What was my question? Well, we were talking about ... let's move on because I don't remember 
what it was!

Sato: So, the general view among Japanese cinema fans was the greatest filmmakers at that time were Ozu and Mizoguchi, and that Kurosawa may surpass these two. That's the general idea. But Ozu's films were probably not well understood by the foreign people because his films were too quiet. But some people might argue that because his films are quiet, they're very Japanese. But Ozu actually described, depicted his perception of beauty and his perception of morals. He just described these and he didn't mind whether it was Japanese or not. Not logical, but it's whether you like the film or not.

Author: [To translator: Now can I ask a question that I haven't given you?]. Were Ozu's films popular in Japan in the 1950s? I'm thinking because at that time cinema was changing. There were new kinds of cinema coming in, including a genre called the taiyozoku, Sun Tribe in English, so was Ozu popular with audiences here in Japan in the 1950s?

Sato: I think back then there were two types of people. One type saw Ozu as a god. These are people who think the moral and the [word that's difficult to discern now] from the pre-war period is important. And the other type is the postwar period type, these are largely young people who had their ... who were young during the war time ... these people after the war actually tried to oppose Japanese society by copying American cinema. They tried to express their opposition towards Japanese society. But I think this is not only true of Japan, worldwide this was seen.

Author: Yes.

Sato: I think people's mindset changed in the postwar period, those people called bosozoku or Japanese gangsters. They will not keep on being a gangster when they grow old. The same is true with people who try to do demonstrations outside, those left-wing people, they don't remain leftist when they are old. [Again, chuckles while answering this question.]

Sato: So, you know, it's up to what age you are, how old you are, it's OK if the mood is for being wild ... if people are too wild then people will think: oh, I cannot find a job if I keep on being wild as this.

Sato: I think Ozu's film can be appreciated by anybody ... some people may think his style is old, but I think it is now widely appreciated.

Author: And were Ozu's films popular in Japan in the cinema in the 1950s? Or did he face difficulties because of challenges?

Sato: I think he had a stable popularity. I think $50 \%$ of Japanese people unconditionally understood his films, and the remaining may think his style is old and maybe others think his style, that's how it is.

Author: That's really helpful. I think we've covered most of my big questions. Just to ask Sato-sensei if there is anything else he would like to say about Ozu, Tokyo Story and the 1950s because it was an amazing time for cinema, exciting, dynamic, international, and if he had anything else he wanted to think about or say about that period.

Sato: The defeat of the war was pretty much of a shock to the Japanese people, psychologically, so Japanese people did a thorough soul searching and there was one group of people who thought a new world class ideologically would not be appreciated unless we said goodbye to the old days, to deny the old. On the other hand, there was another group who thought militarism was totally a mistake but it was not easy to change .... So there were two types of people who thought it was important to maintain the old ideology while there was another [group] who thought that breakthrough cannot be obtained unless we collapse the old system, so those people who thought that we need to break from the old era were trying to find a typical idea and that came from Ozu, because Ozu never denied the old things. To study, to find something, to find a breakthrough, if people study Ozu's film works, and these were the young generation people who were exemplified by Nagisa Oshima, he might be the typical type of this generation who thought he needed a new ideology. And another might be Masumura Yasuzo and Shohei Imamura who were ages around 27 to 28 in the postwar period at the mid-1950s who became assistant directors, and 
they tried to find different kinds of film work from Ozu because they thought that Ozu was the typical kind of film work that is close with the old. So Ozu was in a sense, for them, a hero who needed to be collapsed.

Author: I see. Taken down, yes, ok. Well, that's all wonderfully helpful and I don't have any further questions about this right now but thank you so much.

Sato: So, I am also the same generation as Oshima and Imamura and I'm not saying that Ozu is not bad or not good. It's not denying Ozu. It's that to make a new worldly society we need to part from Ozu, change into a new style, that's the idea.

Author: I understand. Thank you very much. 
Appendix B: Interview with Leslie Hardcastle

Written consent for this interview and its use by the author was given at the outset of this interview.

Interviewee: Leslie Hardcastle, former controller of the BFI's National Film Theatre.

Interviewer: The author.

Interview time and date: May 9, 2018, 11am-1pm

Location: Soho, London, UK.

Additional information: This transcript has been lightly edited for clarity, brevity and relevance.

Leslie Hardcastle: Originally it [the London Film Festival] was a festival of festivals. It took all the prize winners. Didn't make its own choices. It took all the prize winners from all the other European film festivals. And then, of course it developed into choosing its own films and then having different aspects of filmmaking that they went for. But originally it was the festival of festivals and it's still regarded as one of the best festivals.

The Author: It's huge now. I think it was much better when it was 18 films, to be honest.

LH: Yup, yup. Well, we were the same. We had 18 fantastic films. It was amazing in those days. We had no money. We had to pay from the takings. So, we had all these ticket applications coming in but the film, commercial film renters here, would only allow us to have two screenings of any film because they would then be distributing them around the country and they were very restrictive and difficult, the commercial filmmakers, not makers, distributors. And so we got all this money and we had to send it back because all the tickets had gone. We got the money we wanted ... so we got all the staff, all the staff, which was, at that time, about 28, and we all sat down and we rang and said 'Look, you've booked this ticket, but we can't give it to you, but there's this other film, this is a Japanese film, Tokyo Story, come and see that. It was crazy.

TA: Is that how it worked? I have spent more time in the BFI archives now and I've gone through all kinds of letters and correspondence and documents, including Derek Prouse and John Gillett and Dilys Powell, and in fact I've read some of the things you've wrote as well, around the period you were there, and I did want to talk to you more about the securing aspects of the film.

LH: There was absolute aggression from the commercial film industry to anything like a film society or a film theatre or a festival because they saw it ... they had a feeling as you were getting their business away from them.

LH: It was a highly competitive thing. So now we want a film festival. But first we want a film theatre. The commercial industry said to us, the British Film Institute, who didn't have a cinema, where the French and the Americans and the Russians had cinemas for their film institutes, they said 'You can have the cinema, but you've got to run on a membership basis'. You can't just walk in because you'll be in competition to us.

LH: The French were dominating film festivals in Europe. Now there's a film festival every day. But then there were a few festivals, and they were just as difficult and competitive as the commercial film industry, because that's how you did things in those days. And they said 'You can only have a festival at this time of year' 'You mustn't show that because we want to show that at Cannes, because we want to be first, and then Venice would do the same thing backwards, and all that kind of business ... we had some cinemas in London ... which were only showing specialised foreign films, like we would, and they went to Cannes and places like this, and they negotiated and they were going to pay money to pay for distribution of films in Great Britain, so they had first pecking order over us. BFI was going to show for free, to a membership audience, for showing two showings only. In those days we were just trying to get under the barb wire. 
That was the atmosphere ... We just wanted to show film as an art form ... it was a really pioneering thing. You had to fight to exist.

LH: We had the famous John Gillett, who fell in love with Japan. Japan belonged to him. Russia belonged to David Robinson. You had Richard Roud, France belonged to Richard Roud, so it all became highly specialised. It was coming out of the work done by Madame Kawakita that the Cannes Film Festival, which John Gillett went to, he was in that audience when that first Kurosawa film was shown, Rashomon. And of course don't forget Madame Kawakita is the link.

TA: Yes, she was the link, wasn't she.

LH: She was introducing European cinema to Japan, that was her intention, but in so doing, she was introducing Japanese cinema to Europe. Because until you saw Rashomon and Kurosawa and people didn't realise Kurosawa, Ozu all these directors they were in the silent period as well as the sound ... and we didn't know it. That was really a key point.

LH: Everything we achieved, we achieved against great resistance. It isn't here now. People go to Toronto, they go to Sundance, they to go Cannes, they fight to get their films shown, they fight to get their films shown at the London film Festival. It wasn't then, they wouldn't let you have their film.

TA: [Asks about film scripts and subtitling]. For me I am quite fascinated by that.

LH: Sometimes we had a script. Other times we had to have a translator translate the original script making a script so the commentator could actually read from it. Just like the pianist. The great Russian films had scores by great Russian composers. Out of that period ... I would say out of all these foreign films that we had, the Communist films were more likely to be in English than films not from communist countries, and that was a purely propaganda thing. They made certain their films were going to be shown in the country, how great their country, communism was, and they subtitled for that purpose.

TA: So, the Communist countries, kinda using cinema as a soft power. So, the Russians were very active, it seems, in using it as a form of soft power.

LH: Yes, definitely ... People that made films in Japan, in France, in Taiwan, in Argentina, they just made films for their local audiences. Somebody had to subtitle it. And at that time they had to find the money to do that. The kind of films shown in specialised film theatres, someone paid for it.

TA: So, the Communists were already doing that, using film as a way of influencing opinions about their state, and my contention is that, not necessarily that it was a state programme for Japan, but there were some Japanese people who appreciated the same kind of idea. And if you're saying the Russians did it, and Madame Kawakita roamed through Europe, and would have had exposure to what the Russians are doing, and she's my link, so presumably she would have seen what the Russians were doing with using film to influence opinions. And she would have realised possibly that she could do the same thing.

LH: We were talking about very competitive era commercially. Politically, I wasn't brought up to like Japanese ... that was a thing of the time. We'd just won a war. I don't think the Japanese liked us very much. We did drop a bomb, a couple of bombs on them. They had a very bitter war with the Americans.

TA: In the 1950s, Japan had a public relations problem, as we might say.

LH: The Japanese had a big tradition of great directors in the silent period. We didn't know about them. It was people like Richie and John Gillett. The Japanese owe a lot to John Gillett. Nobody really talked about John Gillett, but I know John.

TA: I've read John Gillett's papers. I can see he has a very close relationship with Madame Kawakita. There are tons of letters back and forth. And I can see that he was passionate about Japanese film.

LH: He was.

TA: But what got him started?

LH: I told you, he was sitting into that cinema, when Rashomon was being shown. Probably Richie, I don’t 
know about whether he was before John Gillett.

TA: I want to talk to you about Donald Richie in a minute, he's on my list.

LH: I didn't know him very much. John Gillett, we used to have rows every month ... each brochure was different, represented a season ... and John Gillett always had his Japanese films. He didn't stop at Ozu, he went through the whole lot. And he would say, 'I want the front cover'. And we'd say 'No John, you can't have the front cover'. He was really passionate.

TA: Was there any kind of Japanese government involvement in any of the film festivals that you participated in, in the fifties, or were aware of?

LH: I'm laughing because we had one director who insisted that the national anthem of the country concerned be played before each film. And we had a Japanese ambassador coming to one of these Japanese films, and I remember saying to Mike Weston, who was the manager, 'Has it arrived yet, have they got the record for the Japanese anthem' ... Mike Weston said 'No, but they're sending sheet music. Sending sheet music! What are we supposed to do!' Japanese ... we're sending sheet music ... I always remember that.

TA: So, it was not unusual, then, for a nation to have its anthem played before the screening of a foreign film. So, there was a direct link to nationalism and cinema.

LH: Yeah, yeah.

TA: It was almost a state occasion. There was, in some senses, some kind of government involvement in those days.

TA: You met Madame Kawakita many times.

LH: Yes, yes.

TA: Do you ever remember having any kind of conversations with her, or getting a sense ... like what do you think motivated her?

LH: She was married to one of the major executives of a major film company, so she must have had an interest ... she was, well, she was the lady in purple. Everything was purple. Purple pen, purple paper, and she always wore the kimono. She was always regally, what's the word, she was very light, very feminine, she had a very Japanese style, and she had a brain like a Burroughs adding machine. She was absolutely wonderful. At the Cannes Film Festival everybody wanted to go to the Japanese reception, it was the one you went to, because they gave you presents, they gave you pens.

TA: She was a very savvy businesswoman by the sounds of it.

LH: [Talked about Derek Prouse hosting parties with industry insiders.] He specialised in world games, and I've seen Mrs. Kawakita after dinner go with the rest of the guests and they used to play this Japanese card game. She had a fantastic brain.

TA: Obviously there was a business aspect, and a financial aspect, but it sounds to me like there was more to it for her. What do you think motivated her? Do you think she loved film? She loved filmmaking?

LH: Oh, she loved film, she loved film. She was introducing Europe to Japan, and in so doing she introduced Japan to us.

TA: Can I just ask you about Donald Richie because you've mentioned him a couple of times. And Donald Richie and Kawakita, I have learned from reading vastly, they were quite close friends, they knew each other very well. Did you ever meet Donald Richie?

LH: I didn't meet him deeply. I can talk quite deeply about all these other people. I suppose because he was so involved with John Gillett, I never got near him.

TA: He was involved with John Gillett, was he, quite heavily?

LH: Yes, yes, yes. 
TA: OK. [AD speaks about UCLA Japanese film screenings of 1956 and Richie correspondence with UCLA film studies academic Harold Leonard].

LH: A lot of things have happened to me. I do remember very clearly, and I wasn't part of instigating it, because I was the organiser of these things, because of the complexity of the people I was working with ... I was always ... aware of the pain of achieving what had to be achieved.

And I remember that when we showed Tokyo Story, no, it was when, when we awarded Ozu the Duke of Sutherland's award, the BFI award, at that time, there was a great fight going on but there was a delay because John Gillett had actually said that we must, not only because it was a great film, we must do it for Ozu because he's not flourishing at this moment in his own country. We must see ... it'll do a great deal of good to him if he wins the BFI award for Tokyo Story. And I remember that argument.

TA: So, John Gillett, who was he having an argument with for that?

LH: I don't think it was an argument whether we should do it or not. He was doing it, and he was delaying things. And I do know he won the argument. It was good to delay. To achieve this award for Ozu, for Tokyo Story, because it would do him good in his present situation in Japan.

TA: I tried to find information about how that award, anything written down, in all the ephemera at the BFI, and there was nothing.

LH: I think there isn't. It was kind of a group of people there, um. It'd be the programme officer at the BFI. Sight and Sound.

TA: Sight and Sound, Gavin Lambert, did you know him? [TA cites Richie letter in 1955 to Leonard.] So even in 1955 they're talking about this Japanese season in London, that's the Light in the Japanese Window.

LH: That's the season that followed the London Film Festival.

TA: Correct.

LH: The first one. The first main season. Then, after that, they came through John Gillett's efforts, they came quite often.

TA: [Talking about Dilys Powell]. She does sound like she was well connected. [Cites Powell invitation to Olivier and Leigh to dinner party night of inaugural London Film Festival]. When I read all these bits of paper that she had bashed off, these notes, I could see that she was one of these people who is a networker, who connects people together. And I thought that was really influential ...

LH: Yes, yes. Definitely.

TA: I guess you weren't invited, Leslie?

LH: I wasn't big enough then.

TA: You saw it all, you were there, you witnessed it, you lived through it. Do you think that the Japanese films that were show in that period, in the 50s, what kind of impact do you think they had on the audience and on perceptions of Japan?

LH: I think they must have had an effect.

TA: Do you think they softened the perceptions of Japan?

LH: Oh yes, they must have done. Because Tokyo Story is the most fantastic film about human relationships within a family, so I think they must have been ... It was a different period. We did not like the Japanese. So, I think just by virtue of seeing that they were normal human beings, and made by a sensitive director, must have had some effect on thinking people. I don't think they had much effect on people who had been doing the fighting. I always remember, my doctor saying, after my father died, 'war doesn't end at the Armistice'.

TA: I think it's quite interesting what you just said, that war doesn't end at the Armistice. And it takes generations for things to change. 
LH: I tell you one thing, it was fun. It was terrific fun ... to suddenly discover Japan, to discover French Canada or Argentina. You'd never go there. I've been to all these countries through film.

TA: You've been very, very fortunate to have been involved with film. 


\section{Works Cited}

Academy of Motion Picture Arts and Sciences

http://www.oscars.org/oscars/ceremonies/1952/memorable-moments

Accessed August 21, 2018.

Anderson, Joseph L. and Richie, Donald 1982 [1959]. The Japanese Film: Art and Industry, Expanded Edition. Princeton, NJ: Princeton University Press.

Armendáriz-Hernández, Alejandra and González-López, Irene 2017. "Roundtable: The Position of Women in Post-War Japanese Cinema (Kimena Junpo, 1961)”. Film Studies 16, Spring 2017: 36-55.

BFIa, various dates. "British Film Institute Archive". ITM-11375, File 3, National Film Theatre. Viewed courtesy of the BFI Special Collections Team. London: BFI.

BFIb, various dates. "John Gillett Collection". ITM-17529, Box 5. Viewed courtesy of the BFI Special Collections Team. London: BFI.

BFIc, various dates. “John Gillett”. Folder labelled Japanese Cinema, ITM-17530, Box 6. Viewed courtesy of the BFI Special Collections Team. London: BFI.

BFI 1957. “A Light in the Japanese Window”. Progxramme for a Japanese season of film at London's National Film Theatre. London: BFI.

BFI 1957-58. "London Film Festival/Dilys Powell”. Correspondence regarding the First and Second London Film Festivals, ITM-17768, Box 5. Viewed courtesy of the BFI Special Collections Team. London: BFI.

BFI 1976. Yasujiro Ozu, A Critical Anthology. Eds John Gillett and David Wilson. Viewed courtesy of the Kawakita Memorial Film Institute Tokyo, Japan. London: BFI.

BFI 2002. "NFT 50". Material Relating To Nft50 - National Film Theatre 50th Anniversary Gala 20 October 2002. ITM-8784, Box 103. Viewed courtesy of the BFI Special Collections Team. London: BFI.

Bordwell, David 1988. Ozu and the Poetics of Cinema. Princeton, NJ: Princeton University Press.

Brennan, Marjorie 2015. "60 years of the Cork Film Festival”. The Irish Examiner. http://www.irishexaminer.com/lifestyle/features/60-years-of-the-cork-film-festival-362275.html Accessed 4 January 2017.

British World News, 1956. DVD, produced by Gaumont. Viewed courtesy of the Kawakita Memorial Film Institute, Tokyo, Japan.

Burch, Noël 1979. To the Distant Observer, Form and Meaning in the Japanese Cinema. London: Scolar Press.

Buruma, Ian 2018. A Tokyo Romance, A Memoir. London: Atlantic Books.

Davis, Darrell William 1996. Picturing Japaneseness, Monumental Style, National Identity, Japanese Film. New York: Columbia University Press.

Desser, David 1997. “A Filmmaker for All Seasons”. In Ozu's Tokyo Story, ed. by David Desser, 1-24. Cambridge: Cambridge University Press.

Dower, John W. 1999. Embracing Defeat: Japan in the Wake of World War II. New York: W.W. Norton \& Company/The New Press.

Gibbs, Michael H. 2012. "Film and Political Culture in Japan". In Framing Film, The History \& Art of Cinema 15, ed. by Frank Beaver. New York: Peter Lang.

Gillett, John 1956. "Cork en Fete”. Sight and Sound 26 (1): 5-6. London: BFI.

Gillett, John 1994. "Homage to the Kawakitas: Between Europe and Japan”. National Film Theatre Programmes 1 (10): 9-11. London: BFI.

Hardcastle, Leslie 1995. “obituaries: John Gillett”. Independent, 13 December 1995. https://www.independent.co.uk/news/people/obituaries-john-gillett-1525498.html 
Accessed 14 August 2018.

Higbee, Will and Lim, Song Hwee 2010. "Concepts of transnational cinema: towards a critical transnationalism in film studies". Transnational Cinemas 1: 1, 7-21.

High, Peter B. 2003. The Imperial Screen, Japanese Film Culture in the Fifteen Years' War 1931-1945. Madison, Wisconsin: University of Wisconsin Press.

Higson, Andrew 2000. "The Limiting Imagination of National Cinema". In Cinema and Nation, eds Mette Hjort and Scott MacKenzie, 58-68. Published in the Taylor \& Francis e-Library, 2005. New York, London: Routledge.

Hjort, Mette 2010. "On the Plurality of Cinematic Transnationalism”. In World Cinemas, Transnational Perspectives, eds Nataša Durovicová and Kathleen E. Newman, 12-33. New York: Routledge.

Ireton, Glenn F. 1955. “Japan to Form Film Consultative Council”. The Film Daily, 5 October 1955, 108 (67): 1.

Ishiguro, Kazuo 2017. "My Twentieth Century Evening - and Other Small Breakthroughs". https://www.nobelprize.org/nobel_prizes/literature/laureates/2017/ishiguro-lecture_en.html. Accessed 29 April 2018.

Japan Motion Picture Almanac 1957. Compiled by Jiji Tsushinsha. Published by the Promotion Council of Motion Picture Industry of Japan, Inc. Viewed courtesy of the Shochiku studio archives, Tokyo, Japan.

The Japan Times 1956. "Modern Japan Films to be Shown at UCLA”. 22 March 1956: 4. No known author. Accessed 4 December 2017 via The Japan Times online archive.

Japanese Films 1958. Eds Kyusaku Hori and Nagamasa Kawakita. Published by UniJapan Film/Association for the Diffusion of Japanese Films Abroad, Inc. Viewed courtesy of the Shochiku studio archives, Tokyo, Japan.

Japanese Films 1959. Published by UniJapan Film/Association for the Diffusion of Japanese Films Abroad, Inc. Viewed courtesy of the Shochiku studio archives, Tokyo, Japan.

Joo, Woojeong 2017. The Cinema of Ozu Yasujiro, Histories of the Everyday. Edinburgh: Edinburgh University Press.

Kawakita, Kashiko 1990. "Correspondence with John Gillett about screenings of Japanese cinema”. John Gillett documents. ITM-17530, Box 6. Viewed courtesy of the BFI special collections team, London, UK.

Kawakita, Kashiko 2017. "BAFTA Award Ceremony”. Eiga Hitosujini, 268-270, citing Nikkan Sports, 15 March 1956. Tokyo: Nihontosho Centre. Translation Sawako Irie.

Kishi, Nobusuke 1957. “Japan in 1957”. Contemporary Japan XXIV (10-12): 553-557.

Loewenthal, Wynn 1955a. “Shochiku Seeks More From U.S. Market”. The Film Daily, 4 October 1955, 108 (66): 1.

Loewenthal, Wynn 1955b. “50-100 Imports To Theatres in 12 Months”. The Film Daily, 31 October 1955, 108 (84): 1.

Lowitz, Leza 2004. “Introduction”. In The Japan Journals by Donald Richie, ed. by Leza Lowitz, VII-XIV. Berkeley: Stone Bridge Press.

Manning, Cian, date unknown. "Hidden Gems and Forgotten People, Dermot H. Breen: Founder of the Cork International Film Festival”. Waterford Archaeological \& Historical Society.

http://www.hidden-gems.eu/waterford-dermothbreen.pdf.

Accessed 31 August 2018.

Mansfield, Stephen 2013. “An inclined view: The life and work of Donald Richie”. The Japan Times, 24 February 2013.

https://www.japantimes.co.jp/culture/2013/02/24/films/an-inclined-view-the-life-and-work-of-donald- 
richie/\#.WIDvwRTPzu1

Accessed 3 December 2017.

Mellen, Joan 1975. "Mme. Kashiko Kawakita”. In Voices from the Japanese Cinema, ed. by Joan Mellen, 5971. New York: Liveright.

Miner, Earl 1956. “Japanese Film Art in Modern Dress”. The Quarterly of Film Radio and Television 10 (4): 354-363.

http://www.jstor.org/stable/1209782.

Accessed 4 December 2017.

Miner, Earl 1958. The Japanese Tradition in British and American Literature. Princeton: Princeton University Press.

Monthly Film Bulletin 1965. Tokyo Monogatari (Tokyo Story), Japan 1953. May 196532 (376): 73. London: British Film Institute.

Motion Picture Daily 1958a. "Films a Unifying Force, Johnston Tells Japanese”. 23 January 1958, 83 (16): 3.

Motion Picture Daily 1958b. “Cites Role of Films In Aiding World Peace”. 28 January 1958, 83 (19): 3.

Nixon, Richard M. 1953. “To the Japanese People”. Contemporary Japan XXII (7-9): 363-378.

Nolletti Jr., Arthur 1997. “Ozu's Tokyo Story and the "Recasting” of McCarey's Make Way for Tomorrow”. In Ozu's Tokyo Story, ed. by David Desser, 25-52. Cambridge: Cambridge University Press.

Nye, Joseph 1990. Bound to lead: The changing nature of American power. New York: Basic Books.

Ochiai, Emiko 2000. "Debates over the Ie and the Stem Family: Orientalism East and West". Japan Review (12): 105-128.

Ozu, Yasujiro 1996. Carnets 1933-1963, Edition intégrale. Translated from Japanese into French by Josiane Pinon-Kawatake. Paris: Editions Alive. Translation from French into English, author's own.

Powell, Dilys 1958. "Festival Fever". International Film Annual, No. 2. In The Dilys Powell Film Reader, 1991, ed. by Christopher Cook, 430-435. Oxford and New York: Oxford University Press.

Quiñones, Eric 2004. "Earl Miner, specialist in English and Japanese literature, died at age 77". Princeton Weekly Bulletin 93 (26).

https://pr.princeton.edu/pwb/04/0503/2a.shtml

Accessed 31 August 2018.

Raine, Michael 2005. “Crazed Fruit: Imagining a New Japan - The Taiyozoku Films”. The Criterion Collection 28 June 2005.

https://www.criterion.com/current/posts/373-crazed-fruit-imagining-a-new-japan-the-taiyozoku-films Accessed 16 July 2018.

Rayns, Tony date unknown. “Tokyo Monogatari (Tokyo Story)”. In Ozu's Tokyo Story, ed. by David Desser, 163-167. Cambridge: Cambridge University Press.

Richie, Donald 1955a. "Letter to UCLA film academic Harold Leonard on a proposed Japanese film season and general reflections on the state of Japanese cinema, 22 November 1955”. Harold Leonard motion picture research files, circa 1940-circa 1960. UCLA Catalog Record ID 6982553, Box 29, Folder 16, 1-4. UCLA Library Special Collections, Charles E. Young Research Library, UCLA. Many thanks to the UCLA Library Special Collections team for assistance.

Richie, Donald, 1955b. "Followup letter to UCLA film academic Harold Leonard on a proposed Japanese film season and general reflections on the state of Japanese cinema, 16 December 1955". Harold Leonard motion picture research files, circa 1940-circa 1960. UCLA Catalog Record ID 6982553, Box 29, Folder 16, 1-2. UCLA Library Special Collections, Charles E. Young Research Library, UCLA. Many thanks to the UCLA Library Special Collections team for assistance.

Richie, Donald 1974. Ozu: His Life and Films. Berkeley, CA: University of California Press. 
Richie, Donald 2004. The Japan Journals: 1947-2004. Ed. by Leza Lowitz. Berkeley, California: Stone Bridge Press.

Robinson, David, 1987. “Travels with Mrs Kawakita”. Sight \& Sound 56 (4): 253-255. London: BFI.

Roud, Richard 1983. A Passion For Films: Henri Langlois And the Cinémathèque Française. New York: The Viking Press.

Sato, Tadao 1982. Currents in Japanese Cinema. Translated from Japanese by Gregory Barrett. New York: Kodansha USA Inc.

Sato, Tadao 2013. "The champion of Ozu's masterwork 'Tokyo Story”. The Japan Times, 24 February 2013. https://www.japantimes.co.jp/culture/2013/02/24/films/the-champion-of-ozus-masterwork-tokyostory/\#.WiRjHxTPzu0

Accessed 3 December 2017.

Sharp, Jasper 2011. “Ozu Yasujirō”. In Historical Dictionary of Japanese Cinema, 194-196. Lanham, MD: Scarecrow.

Shaw, Deborah 2013. "Deconstructing and Reconstructing 'Transnational Cinema”. In Contemporary Hispanic Cinema: Interrogating Transnationalism in Spanish and Latin American Film, ed. by Stephanie Dennison, 47-66. Woodbridge, UK: Tamesis.

Sight and Sound 1955/56. “The Front Page”. Winter 1955/56 25 (3): 114.

Sinica podcast. Joseph Nye, Jr: Chinese power in the age of Donald Trump. https://supchina.com/podcast/joseph-nye-jr-chinese-power-age-donald-trump/ Accessed 18 May 2017.

Standish, Isolde 2005. A New History of Japanese Cinema. New York, London: continuum.

Sweeney, Maxwell 1956. "Chronicle: Cork Film Festival”. The Furrow 7 (7): 418-420 http://www.jstor.org/stable/27656969

Accessed 5 December 2017.

Tezuka, Yoshiharu 2012. "Internationalization of Japanese Cinema”. In Japanese Cinema Goes Global, Filmworkers’ Journeys, 25-73. Hong Kong: Hong Kong University Press.

Tokyo Story 1953. DVD. London: BFI.

Ueno, Ichiro 1954. "Motion Picture Industry”. Contemporary Japan XXIII (1-3): 57-74.

Ulfsdotter, Boel 2008. An invitation to travel: the marketing and reception of Japanese film in the west 19501975. University of Reading, $\mathrm{PhD}$ thesis.

http://www.cinemateria.se/Ulfsdotter_diss.pdf

Accessed 18 August 2018.

UniJapan Film Quarterly 1959. Establishment of the Federation of Japanese Film Industry, Inc. January 1959, 2-3.

Walsh, Kevin 1957. "The Cork Film Festival”. The Furrow 8 (7): 467-470.

http://www.jstor.org/stable/27657208.

Accessed 4 December 2017.

Bibliography

Andersen, Thom 2016. "Ozu Yasujirō: the master of time”. Sight \& Sound.

http://www.bfi.org.uk/news-opinion/sight-sound-magazine/features/greatest-films-all-time/ozuyasujiro-master-time.

Accessed 23 November 2017. 
Anderson, Lindsay 1957. "Two inches off the Ground”. Sight \& Sound 27(3): 131-133, 160. London: BFI.

Asahi Shimbun Company 2015. Media, Propaganda and Politics in 20th-Century Japan. Translated from Japanese by Barak Kushner. London: Bloomsbury.

Auty, Martyn, Hartnoll, Gillian 1981. Water Under the Bridge: 25 Years of the London Film Festival. BFI Dossier No.12. London: BFI.

Bafta. Entry on United Nations Award, 1956. http://awards.bafta.org/award/1956/film/united-nations-awards

Accessed 11 August 2018.

Baughan, Nikki 2016. "A Brief History of the London Film Festival”. http://www.bfi.org.uk/news-opinion/news-bfi/features/brief-history-bfi-london-film-festival Accessed 23 November 2017.

BBC Radio 3. "Tokyo Story”. Night Waves, Landmarks. Broadcast 18 December 2013. https://www.bbc.co.uk/programmes/b03lnfss Accessed 2 September 2018.

BBC Radio 4. "Dilys Powell”. Desert Island Discs. Broadcast 28 August 1992. http://www.bbc.co.uk/programmes/p0093ym6 Accessed 23 November 2017.

Bell, James 2012. Ozu Yasujirō. Sight \& Sound 22 (9): 51.

Benedict, Ruth 1964. The Chrysanthemum and the Sword. First Mariner Books Edition, 2005. Boston, New York: Houghton Mifflin.

BFI, no known date. "British Film Institute (BFI) Archive". ITM-11531, File 7. Viewed courtesy of the BFI Special Collections Team. London: BFI.

BFI, no known date. "John Gillett”. ITM-17525, Box 1. Viewed courtesy of the BFI Special Collections Team. London: BFI.

BFI, no known date. "National Film Theatre, British Film Institute (BFI) Archive”. ITM-11895, Blue Box file. Viewed courtesy of the BFI Special Collections Team. London: BFI.

BFI, various dates. "British Film Institute Archive: National Film Theatre". ITM-11375, File 3. Viewed courtesy of the BFI Special Collections Team. London: BFI.

BFI 1930s-1950s. "British Film Institute (BFI) Archives: British Film Institute at the Institut Francaise Theatre, London”. BFI reference: COL-33. Viewed courtesy of the BFI Special Collections Team. London: BFI.

BFI 1952-1958. "British Film Institute (BFI) Archives". ITM-9939, Box 108. Viewed courtesy of the BFI Special Collections Team. London: BFI.

BFI 1957. "Programme Planning”. London Film Festival, commemorative programme,15 October 1957. Viewed courtesy of Leslie Hardcastle, London, UK.

BFI 1958-1995. “John Gillett”. ITM-17526, Box 2. Viewed courtesy of the BFI Special Collections Team. London: BFI.

BFI 1987-88. "British Film Institute (BFI) Archive”. ITM-15906, Box number 6, Leslie Hardcastle. Viewed courtesy of the BFI Special Collections Team. London: BFI.

BFI. Tokyo Story.

http://www.bfi.org.uk/films-tv-people/4ce2b6b8908e4

Accessed 23 November 2017.

Bradshaw, N. 2010. "Leo McCarey is best remembered for his comic work with Laurel \& Hardy, the Marx Brothers and Cary Grant. But his tragic 1937 family drama Make Way for Tomorrow influenced Tokyo Story”. Sight and Sound 20 (11): 38-41. London: BFI. 
British Pathé 2014. London Film Festival (1958).

https://www.youtube.com/watch?v=SZYs27KPuMY

Accessed 2 December 2017.

The Daily Cinema 1965. No 9028, 15 February 1965: 4. No known title.

Deveney, Abigail 2018. "Bridging a narrative gap: reconsidering how, and when, Yasujirō Ozu's Tokyo Story broke through in the west". Coursework, written for Japanese Transnational Cinema: From Kurosawa to Asia Extreme and Studio Ghibli (15PJKH007-A17/18) AS2, SOAS, University of London.

Ebert, Roger, 1993. "Saluting a Master of the Cinema, Yasujiro Ozu". https://www.rogerebert.com/interviews/saluting-a-master-of-the-cinema-yasujiro-ozu. Accessed 2 August 2018.

Eiga Nenkan 1956. Viewed with the kind assistance of Keio University reference library staff, Tokyo, Japan. Translation Sawako Irie. Tokyo: Jiji Eiga Tsushinsha.

Eiga Nenkan 1958. Viewed with the kind assistance of Keio University reference library staff, Tokyo, Japan. Translation Sawako Irie. Tokyo: Jiji Eiga Tsushinsha.

Eiga Nenkan 1959. Viewed with the kind assistance of Keio University reference library staff, Tokyo, Japan. Translation Sawako Irie. Tokyo: Jiji Eiga Tsushinsha.

The Film Daily 1955. “Kobayashi Heads MPAJ (Motion Picture Association of Japan)”. 13 December 1955 108 (113): 6.

Film Facts 1972, 15 (7): 141-144. No known title. No known author.

Films and Filming July 1965, 11 (10): 33. "Tokyo Story”. No known author.

Fong, Gilbert Chee Fun, and Au, Kenneth K. L. 2009. Dubbing and Subtitling in a World Context. Hong Kong: Chinese University Press.

Gabert, Roger 1952. "Les Sous-Titres de Film”. Cahiers du Cinema 1 (10). Translation, author's own.

Gillett, John 1958. "International Film Correspondence letter to John Gillett from M Iwabutchi, Tokyo". ITM-17525, Box 1. Viewed courtesy of the BFI Special Collections team. London: BFI.

Haag, Michael 1995. "Obituary: Dilys Powell”. Independent. https://www.independent.co.uk/news/people/obituarydilys-powell-1585062.html Accessed 23 November 2017.

Harada, Jiro 1953. “Japanese Art Exhibitions in U.S.A.”. Contemporary Japan XXI (10-12): 617-630.

Hardcastle, Leslie 2008. “James Quinn: Cultured, committed BFI director”. Independent. http://www.independent.co.uk/news/obituaries/james-quinn-cultured-committed-bfi-director-801722. html Accessed 2 December 2017.

Harris, Warren G. 1958. "Kido is a Man With Two Missions”. Motion Picture Daily, 23 January 1958, 83 (16): 3.

Harvard Kennedy School. "Joseph Nye Harvard University Distinguished Service Professor, Emeritus”. https://www.hks.harvard.edu/faculty/joseph-nye. Accessed 28 April 2018.

Hebron, Sandra 2006. "50 Years of the London Film Festival, Part 1: In the Beginning”. National Film Theatre Programmes 1 (7): 20-24. BFI: London.

Higson, Andrew 1989. "The Concept of National Cinema”. Screen 30 (4) Autumn 1989: 36-46.

Hirano, Kyoko 1992. Mr. Smith goes to Tokyo: The Japanese cinema under the American occupation, 19451952. Washington, D.C.: Smithsonian Institute.

IMDb entry for Yasujiro Ozu, awards. https://www.imdb.com/name/nm0654868/awards 
Accessed 28 August 2018.

IMDb entry for Leo McCarey.

https://www.imdb.com/name/nm0564970/awards?ref_=nm_awd

Accessed 11 August 2018.

IMDb entry for Make Way for Tomorrow.

https://www.imdb.com/title/tt0029192/

Accessed 19 July 2018.

Japan Knowledge. Encyclopedia of Japan. Entry on Takahashi Seiichiro.

https://japanknowledge-com.ezproxy.soas.ac.uk

Accessed 20 June 2018.

Japan Knowledge. Encyclopedia of Japan. Entry on Yasujiro Ozu.

https://japanknowledge-com.ezproxy.soas.ac.uk/lib/en/display/?lid=10800PR003010

Accessed 3 August 2018.

Julian-Huxley, Susan and Hartnoll, Gillian 1981. "Filmography and Chronology”. In Water Under the Bridge: 25 Years of the London Film Festival. BFI Dossier No.12. London: BFI.

Kawakita Memorial Film Institute.

http://www.kawakita-film.or.jp/kmfi_english.html.

Accessed 6 December 2017.

Kine Weekly 1965. No 2993, February 11, 1965: 13.

Kriegel-Nicholas, Isadora 2016. "The historical reception of Japanese cinema at Cahiers du cinéma: 19511961”. PhD thesis, Boston University, ProQuest Dissertations.

https://search.proquest.com/pqdthss/docview/1812310494/17A4E4DBD2BE4461PQ/1?account id $=16710$

Accessed 6 December 2017.

Library Guides. Harvard referencing: personal communication.

http://www.libraryguides.vu.edu.au/harvard/personal-communications

Accessed September 3, 2018.

Lopate, Phillip, 1998. "The Subtly Observant Eye”. Cineaste, 23(3): 26.

Los Angeles Times 1956. "Japanese Move Series to Be Shown at UCLA”. 25 March 1956: 12.

Luder, Olivia and O'Kane, Jessica 2013. The London Film Festival.

http://www.bdcmuseum.org.uk/news/the-london-film-festival-by-olivia-luder-and-jessica-o-kane/

Accessed 23 November 2017.

Ministry of Economy, Trade and Industry, History of Meti.

http://www.meti.go.jp/english/aboutmeti/data/ahistory.html

Accessed 2 August 2018.

Motion Picture Daily 1958. “Lunch for Japanese”. 15 January 1958, 83 (10): 4.

Motion Picture Daily 1958. "Japanese Film Week being held at the Museum of Modern Art in NY". 16 January 1958, 83 (11): 6.

Motion Picture Daily 1958. “Japanese Film Festival Opens with Lighthouse”. 22 January 1958, 83 (15): 2.

Motion Picture Producers Association of Japan, Inc (Eiren)

http://www.eiren.org/history_e/index.html

Accessed 6 August 2018.

The New York Times 1995. "Dilys Powell, Film Critic, 93”. 6 June 1995.

http://www.nytimes.com/1995/06/06/obituaries/dilys-powell-film-critic-93.html

Accessed 2 December 2017. 
Nornes, Abé Mark 1999. "For an Abusive Subtitling”. Film Quarterly 52 (3) 3: 17-34.

Nye, Joseph S. 1990. "Soft Power”. Foreign Policy (80): 153-171.

O’Connor, Kieran 1997. "Milk Baths and Monkey Suits: A brief history of the Cork Film Festival”. The Cork Review: 18-21.

https://www.jstor.org/stable/pdf/20768845.pdf

Accessed 5 December 2017.

Okazaki, Tetsuji 1998. "The Government-Firm Relationship in Postwar Japanese Economic Recovery: Resolving the Coordination Failure by Coordination in Industrial Rationalization”. In The Role of Government in East Asian Economic Development: Comparative Institutional Analysis, eds Masahiko Aoki, Hyung-Ki Kim, and Masahiro Okuno-Fujiwara, 74-100. Oxford: Clarendon Press.

Ozu, Yasujirō, Noda, Kōgo 1992. Tokyo Story: the Ozu/Noda screenplay. Translated by Donald Richie and Eric Klestadt. Berkeley, CA: Stone Bridge Press.

Pelegrine, Louis 1955. "Hope for O'seas Films Here Seen in A-1 Dubbing”. The Film Daily, 7 September 1955, 108 (47): 1.

Quinn, James 1964. “Bricks Without Straw”. Film and TV Technician, 30 (233): 120.

Rashomon 1951. The Criterion Collection, 2012.

Richie, Donald 1959. “The Later Films of Yasujiro Ozu”. Film Quarterly 13(1): 18-25.

Richie, Donald 2001. A Hundred Years of Japanese Film. Tokyo and London: Kodansha International.

Roud, Richard 1980. Cinema: A Critical Dictionary. London: Martin Secker \& Warburg Limited.

Sato, Tadao 1976. "From the Art of Yasujirō Ozu". Translated from Japanese by Goro Iiri. Wide Angle 1 (4): 44-48.

Sharp, Jasper 2003. “Donald Richie”. Midnight Eye, December 8, 2003. http://www.midnighteye.com/interviews/donald-richie/

Accessed 5 December 2017.

Shochiku. "History of SHOCHIKU".

https://www.shochiku.com/about/history.html.

Accessed 23 November 2017.

Shochiku. 100 Years, Ozu.

http://www.ozu100.jp

Accessed 2 August 2018.

Solent Online Learning. "Examples of Harvard Referencing: Interviews

https://learn.solent.ac.uk/mod/book/view.php?id=3381\&chapterid=3464

Accessed 3 September 2018.

Stein, Wayne and DiPaolo Marc 2015. Ozu international: Essays on the Global Influences of a Japanese Auteur. London: Bloomsbury Academic.

Takahashi, Sei-ichiro 1955. “Ukiyoé and Western Influence”. Contemporary Japan XXIII (4-6) 332-341.

Yoshida, Kiju 2003. "Films that Imply - On Tokyo Story”. In Ozu's Anti-Cinema. Translated from Japanese by Daisuke Miyao and Kyoko Hirano. Ann Arbor, MI: Centre for Japanese Studies. 